\title{
Function of Prion Protein and the Family Member, Shadoo
}

\author{
Takashi Onodera $^{1 *}$, Takuya Nishimura², Katsuaki Sugiura ${ }^{1}$ \\ and Akikazu Sakudo 3,4
}

\author{
${ }^{1}$ Research Center for Food Safety, Graduate School of Agricultural and Life Sciences, University of \\ Tokyo, Tokyo, Japan. \\ ${ }^{2}$ Pharmaceuticals and Medical Devices Agency, Tokyo, Japan. \\ ${ }^{3}$ Laboratory of Biometabolic Chemistry, School of Health Sciences, University of the Ryukyus, \\ Nishihara, Japan. \\ ${ }^{4}$ Faculty of Veterinary Medicine, Okayama University of Science, Imabari, Ehime, Japan. \\ ${ }^{*}$ Correspondence: takashi.onodera@riken.jp \\ https://doi.org/10.21775/cimb.036.067
}

\begin{abstract}
Lowering cellular prion protein $\left(\mathrm{PrP}^{\mathrm{C}}\right)$ levels in the brain is predicted to be a powerful therapeutic strategy for the prion disease. $\operatorname{PrP}^{\mathrm{C}}$ may act as an antiapoptotic agent by blocking some of the internal environmental factors that initiate apoptosis. Prion protein $(\operatorname{PrP})$-knockout methods provide powerful indications on the neuroprotective function of $\operatorname{PrP}^{\mathrm{C}}$. Using $\operatorname{PrP}^{\mathrm{C}}$-knockout cell lines, the inhibition of apoptosis through stress inducible protein 1 (STI1) is mediated by $\operatorname{PrP}^{\mathrm{C}}$-dependent superoxide dismutase (SOD) activation. Besides, PrP-knockout exhibited wide spread alterations of oscillatory activity in the olfactory bulb as well as altered paired-pulse plasticity at the dendrodendric synapse. Both the behavioural and electro-physiological phenotypes could be rescued by neuronal $\operatorname{PrP}^{\mathrm{C}}$ expression.

Neuprotein Shadoo (Sho), similarly to $\mathrm{PrP}^{\mathrm{C}}$, can prevent neuronal cell death induced by the expression of $\operatorname{PrP} \triangle \mathrm{HD}$ mutants, an artificial PrP mutant devoid of internal hydrophobic domain. Sho can efficiently protect cells against excitotoxin-induced cell death by glutamates. Sho and PrP seem to be dependent on similar domains, in particular $\mathrm{N}$-terminal $(\mathrm{N})$, and their internal hydrophobic domain. Sho $\Delta \mathrm{N}$ and Sho $\Delta \mathrm{HD}$ displayed a reduced stress-protective activity but are complex glycosylated and attached to the outer leaflet of the plasma membrane via glycosylphosphatidylinositol (GPI) anchor indicating that impaired activity is not due to incorrect cellular trafficking. In Sho, overexpressed mice showed large amyloid plaques not seen in wild-type mice. However, Shadoo is not a major modulator of abnormal prion protein $\left(\mathrm{PrP}^{\mathrm{Sc}}\right)$ accumulation. Sho and $\mathrm{PrP}$ share a stress-protective activity. The ability to adopt a toxic conformation of $\operatorname{PrP}^{\mathrm{Sc}}$ seems to be specific for PrP.
\end{abstract}




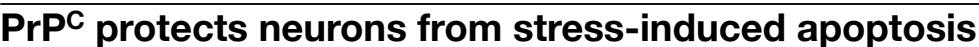

\section{Neurogenesis}

Recently, several reports showed that cellular prion protein $\left(\operatorname{PrP}^{\mathrm{C}}\right)$ participate in a transmembrane signalling process that is associated with haematopoietic stem cell replication and neuronal differentiation (Mouillet-Richard et al., 2000; Steele et al., 2006; Zhang et al., 2006). Abundant expression of $\mathrm{P},, \mathrm{r}^{\mathrm{C}}$ has been detected during mouse embryogenesis in association with the developing nervous system (Manson et al., 1992; Miele et al., 2003; Tremblay et al., 2007). In the developing mouse brain, undifferentiated neural progenitor cells in the mitotically active ventricular zone do not express $\operatorname{PrP}^{\mathrm{C}}$. In contrast, post-mitotic neurons express high levels of $\mathrm{PrP}^{\mathrm{C}}$ after their last mitosis in the neuroepithelium as they migrate towards marginal layers and differentiate (Steele et al., 2006; Tremblay et al., 2007). Thus, $\operatorname{PrP}^{\mathrm{C}}$ may be expressed exclusively in differentiated neurons (Tanji et al., 1995). Studies in vitro have shown that expression of $\mathrm{PrP}^{\mathrm{C}}$ is positively correlated with differentiation of multipotent neuronal precursors into mature neurons (Steele et al., 2006). In addition, treatment of embryonic hippocampal neurons with recombinant $\operatorname{PrP}^{\mathrm{C}}$ enhance neurite outgrowth and survival (Kanaani et al., 2005).

The distribution of $\mathrm{PrP}^{\mathrm{C}}$ in the developing nervous system of cattle (Peralta et al., 2011), as well as in mice (Tremblay et al., 2007) and humans (Adle-Biassette et al., 2006) suggests that $\mathrm{PrP}^{\mathrm{C}}$ plays a functional role in neural development. While mice lacking in prion protein (PrP) display no overt neural phenotype (Beuler et al., 1992), numerous subtle phenotypes have been reported (Steele et al., 2007), including reduction in the number of neural precursor cells in developing mouse embryo (Steele et al., 2006). Other studies have shown that $\mathrm{PrP}^{\mathrm{C}}$ induced neuritogenesis in embryonic hippocampal neurons cultured in vitro (Kanaani et al., 2005; Lopes et al., 2005). $\operatorname{PrP}^{\mathrm{C}}$ interacts with stress-inducible protein 1 (STI1) (Zanata et al., 2002), which is a heat-shock protein (Lässle et al., 1997). The interaction of $\mathrm{PrP}^{\mathrm{C}}$ with STI1 not only activates cyclic adenosine monophosphate (cAMP)-dependent protein kinase A to transducer a survival signal but also induces phosphorylation/activation of the mitogen-activated protein kinase to promote neuritogenesis (Lopes et al., 2005). The expression of mammalian $\mathrm{PrP}^{\mathrm{C}}$ in the neuroepithelium and its spatial and temporal relation with neural marker nestin and MAP-2 also suggests the participation of $\operatorname{PrP}^{\mathrm{C}}$ in the process of neural differentiation during early embryogenesis (Peralta et al., 2011). The use of embryonic stem (ES) cells to study the potential role or $\mathrm{PrP}^{\mathrm{C}}$ will indicate how $\mathrm{PrP}^{\mathrm{C}}$ is up-regulated during the differentiation of stem/progenitor cells.

\section{Neuroprotection}

The mammalian $\mathrm{PrP}^{\mathrm{C}}$ is a highly conserved glycoprotein localized in membrane lipid rafts and anchored to cell surface by glycophosphatidylinositol (GPI) (McKinley et al., 1991). It is present in many cell types and is particularly abundant in neurons (Taraboulos et al., 1992). Under certain conditions $\mathrm{PrP}^{\mathrm{C}}$ may undergo conversion into a conformationally-altered isoform (scrapie prion protein or $\mathrm{PrP}^{\mathrm{Sc}}$ ) widely believed to be the pathogenic agent in prion disease or transmissible spongiform encephalopathies (TSE) (Caughey et al., 1991; Pan et al., 1993). Although much is known about the effect of $\operatorname{PrP}^{\mathrm{Sc}}$ in prion diseases, the normal function of $\mathrm{PrP}^{\mathrm{C}}$ is poorly understood. $\mathrm{PrP}^{\mathrm{C}}$ has an alpha and beta-cleavage site during normal processing and hosts translational modifications (Mange et al., 2004). The most commonly observed function of $\mathrm{PrP}^{\mathrm{C}}$ is copper-binding. The octapeptide-repeat region of 
$\mathrm{PrP}^{\mathrm{C}}$ binds with $\mathrm{Cu}^{2+}$ within the physiological concentration range (Hornshaw et al., 1995; Kramer et al., 2001; Miura et al., 1999; Prusiner, 1997; Zeng et al., 2003). Furthermore, $\mathrm{PrP}^{\mathrm{C}}$ displays a functional role in normal brain metabolism of copper (Brown et al., 1997). Besides binding with $\mathrm{Cu}^{2+}$ at the synapse, $\mathrm{PrP}^{\mathrm{C}}$ serves as a $\mathrm{Cu}^{2+}$ buffer as well (Kretzschmar et al., 2000). Overexpression of $\mathrm{PrP}^{\mathrm{C}}$ increases $\mathrm{Cu}^{2+}$ uptake into cells (Brown, 1999), while $\mathrm{PrP}^{\mathrm{C}}$-knockout mice show a lower synaptosomal $\mathrm{Cu}^{2+}$ concentration than normal mice (Kretzschmar et al., 2000). On the other hand, the $\mathrm{Cu}^{2+}$ rapidly and reversibly stimulates the internalization of $\operatorname{PrP}^{\mathrm{C}}$ during $\operatorname{PrP}^{\mathrm{C}}$ endocytosis (Haigh et al., 2005; Kubosaki et al., 2003; Pauly et al., 1998). Through the binding with $\mathrm{Cu}^{2+}, \mathrm{PrP}^{\mathrm{C}}$ displays superoxide dismutase (SOD) activity in vitro (Brown et al., 1999; Vassallo et al., 2003). Interestingly, treatment with copper chelator cuprizone induces TSE-like spongiform degeneration (Pattison et al., 1973). Therefore, $\mathrm{Cu}^{2+}$ metabolism appears to play an important role in not only $\mathrm{PrP}$ function but also the pathogenesis of prion diseases.

$\mathrm{PrP}^{\mathrm{C}}$ may act as an antiapoptotic agent by blocking some of the factors that initiate apoptosis (Bounhar et al., 2001; Roucou et al., 2005). Mature $\operatorname{PrP}^{\mathrm{C}}$ tend to localize in lipid raft of cells (Taraboulos et al., 1992). As lipid rafts are membrane structures that specialize in signalling, a potential role of $\operatorname{PrP}^{\mathrm{C}}$ in signal transduction may be anticipated. Discovery of several $\mathrm{PrP}^{\mathrm{C}}$-interacting candidates has facilitated the understanding of the $\mathrm{PrP}^{\mathrm{C}}$ function (Table 2.1). $\mathrm{PrP}^{\mathrm{C}}$-interacting molecules are most likely involved in signal transduction. In addition, a phosphorylating function of $\mathrm{PrP}^{\mathrm{C}}$, mediated by caveolin- 1 to indirectly increase Fyn (a member of Src family of tyrosine kinase) phosphorylation, governs the downstream production of nicotinamide adenine dinucleotide phosphate (NADPH)oxidase-dependent reactive oxygen species and activation of the extracellular regulated kinase 1/2 has been demonstrated (Mouillet-Richard et al., 2000; Schneider et al., 2003). $\mathrm{PrP}^{\mathrm{C}}$ interacts with normal phosphoprotein synapsin $\mathrm{Ib}$ and cytoplasmic adaptor protein Grb2 without being deciphered with prion interactor Pint1 (Spielhaupter and Schätzl, 2001). Bovine PrP strongly interacts with the catalytic $\alpha / \alpha \nsubseteq$ subunit of protein kinase CK2 to increase the phosphotransferase activity of CK2, thus leading to the phosphorylation of calmodulin (Maggio et al., 2000).

Recently, $\mathrm{PrP}^{\mathrm{C}}$ has been demonstrated to modulate serotonergic receptor-signalling in the inducible serotonergic 1C115-HT cell line, viz. modulation of 5-hydroxytryptamine (5-HT) receptor coupling to activate G-protein functions, as well as acting as a protagonist to promote homeostasis of serotonergic neurons (Moulliet-Richard et al., 2005). In addition, $\mathrm{PrP}^{\mathrm{C}}$ binds with extracellular matrix laminin to promote genesis and maintenance of neurites (Graner et al., 2000a,b). Indeed, a recent study has discovered $\operatorname{PrP}^{\mathrm{C}}$ to induce self-renewal of long term populating haematopoietic stem cells (Zhang et al., 2006). Furthermore, another study has revealed that PrP is expressed on the multipotent neural precursors and mature neurons without being detected in glia, suggesting that $\operatorname{PrP}^{\mathrm{C}}$ plays an important role in neural differentiation (Steele et al., 2006). Therefore, the interaction between $\mathrm{PrP}^{\mathrm{C}}$ and various signal transduction molecules speaks well for its importance (such as differentiation and cell survival) within the living system.

PrP-knockout methods provide useful hints on the neuroprotective function of $\mathrm{PrP}^{\mathrm{C}}$ (Sakudo et al., 2006). A PrP gene (Prnp)-deficient cell line (HpL3-4), perpetuated from hippocampal neuronal precursors, is sensitive to serum deprivation-induced apoptosis but is activated/survived with $\mathrm{PrP}^{\mathrm{C}}$ expression (Kuwahara et al., 1999). Overexpression of Bcl-2 in this cell-line reveals a functional relation of $\mathrm{PrP}^{\mathrm{C}}$ with $\mathrm{Bcl}-2$ in the anti-apoptotic pathway 
Table 2.1 Proteins interacting with PrP

\begin{tabular}{|c|c|c|}
\hline Proteins & Methods & References \\
\hline Stress-inducible protein 1 & Complementary hydropathy & Martins et al. (1997) \\
\hline Tubulin & $\begin{array}{l}\text { Cross-linking by } \\
\text { bis(sulfosuccinimidyl)-suberate }\end{array}$ & $\begin{array}{l}\text { Nieznanski et al. } \\
(2005)\end{array}$ \\
\hline $\begin{array}{l}\text { Neural adhesion molecule } \\
\text { (N-CAM) }\end{array}$ & Cross-linking by formaldehyde & $\begin{array}{l}\text { Schmitt-Ulms et al. } \\
\text { (2001) }\end{array}$ \\
\hline Dystroglycan & Detergent-dependent immunoprecipitation & Keshet et al. (2000) \\
\hline $\begin{array}{l}\text { Neuronal isoform of nitric } \\
\text { oxide synthase (nNOS) }\end{array}$ & Detergent-dependent immunoprecipitation & Keshet et al. (2000) \\
\hline Grp94 & Immunoprecipitation & Capellari et al. (1999) \\
\hline $\begin{array}{l}\text { Protein disulphide } \\
\text { isomerase }\end{array}$ & Immunoprecipitation & Capellari et al. (1999) \\
\hline Calnexin & Immunoprecipitation & Capellari et al. (1999) \\
\hline Calreticulin & Immunoprecipitation & Capellari et al. (1999) \\
\hline ZAP-70 & Immunoprecipitation & Mattei et al. (2004) \\
\hline $\begin{array}{l}\text { NF-E2 related factor } 2 \\
\text { (Nrf2) }\end{array}$ & $\begin{array}{l}\text { Interaction with PrP23-231-alkaline } \\
\text { phosphatase probe }\end{array}$ & Yehiely et al. (1997) \\
\hline $\begin{array}{l}\text { Amyloid precursor } \\
\text { protein-like protein } 1 \\
\text { (Aplp1) }\end{array}$ & $\begin{array}{l}\text { Interaction with PrP23-231-alkaline } \\
\text { phosphatase probe }\end{array}$ & Yehiely et al. (1997) \\
\hline F-box protein- 6 & $\begin{array}{l}\text { Interaction with PrP23-231-alkaline } \\
\text { phosphatase probe }\end{array}$ & Yehiely et al. (1997) \\
\hline $\begin{array}{l}\text { Neural F-box protein } 42 \\
\text { kDa (NFB42) }\end{array}$ & $\begin{array}{l}\text { Interaction with PrP23-231-alkaline } \\
\text { phosphatase probe }\end{array}$ & Yehiely et al. (1997) \\
\hline $\begin{array}{l}\text { Postsynaptic density } 95 \\
\text { kDa (PSD-95)/SAP-90 } \\
\text { associated protein }\end{array}$ & $\begin{array}{l}\text { Interaction with PrP23-231-alkaline } \\
\text { phosphatase probe }\end{array}$ & Yehiely et al. (1997) \\
\hline $\begin{array}{l}\text { Protein tyrosine } \\
\text { phosphatase, } \\
\text { non-receptor type-21 }\end{array}$ & $\begin{array}{l}\text { Interaction with PrP23-231-alkaline } \\
\text { phosphatase probe }\end{array}$ & Yehiely et al. (1997) \\
\hline $\begin{array}{l}\text { Predicted protein } \\
\text { KIAA0443 }\end{array}$ & $\begin{array}{l}\text { Interaction with PrP23-231-alkaline } \\
\text { phosphatase probe }\end{array}$ & Yehiely et al. (1997) \\
\hline $\begin{array}{l}\text { Glial fibrillary acidic protein } \\
\text { (GFAP) }\end{array}$ & $\begin{array}{l}\text { Interaction with radioisotope-labelled } \\
\text { PrP27-30 }\end{array}$ & Oesch et al. (1990) \\
\hline Hsp60 of Brucella abortus & Pull-down assay & Watarai et al. (2003) \\
\hline $\mathrm{Bcl}-2$ & Yeast two-hybrid system & $\begin{array}{l}\text { Kurschner and } \\
\text { Morgan (1995) }\end{array}$ \\
\hline Heat shock protein 60 kDa & Yeast two-hybrid system & $\begin{array}{l}\text { Edenhofer et al. } \\
\text { (1996) }\end{array}$ \\
\hline $\begin{array}{l}37 \mathrm{kDa} \text { laminin receptor } \\
\text { protein (LRP) }\end{array}$ & Yeast two-hybrid system & Rieger et al. (1997) \\
\hline Pint1 & Yeast two-hybrid system + immunoprecitation & $\begin{array}{l}\text { Spielhaupter and } \\
\text { Schätzl (2001) }\end{array}$ \\
\hline Synapsin lb & Yeast two-hybrid system + immunoprecitation & $\begin{array}{l}\text { Spielhaupter and } \\
\text { Schätzl (2001) }\end{array}$ \\
\hline $\begin{array}{l}\text { Neuronal phosphoprotein } \\
\text { Grb2 }\end{array}$ & Yeast two-hybrid system + immunoprecitation & $\begin{array}{l}\text { Spielhaupter and } \\
\text { Schätzl (2001) }\end{array}$ \\
\hline
\end{tabular}


Table 2.1 Continued

\begin{tabular}{|c|c|c|}
\hline Proteins & Methods & References \\
\hline $\begin{array}{l}\text { Neurotrophin receptor } \\
\text { interacting MAGE } \\
\text { homolog }\end{array}$ & $\begin{array}{l}\text { Yeast two-hybrid system }+ \text { in vitro binding } \\
\text { assay + immunoprecipitation }\end{array}$ & $\begin{array}{l}\text { Bragason et al. } \\
(2005)\end{array}$ \\
\hline $\begin{array}{l}\text { Potassium channel } \\
\text { tetramerization } \\
\text { domain containing } 1 \\
\text { (KCTD1) protein }\end{array}$ & Yeast two-hybrid system & Huang et al. (2012) \\
\hline Rab7a & Coimmunoprecipitation + immunofluorescence & Zafar et al. (2011) \\
\hline Rab9 & Coimmunoprecipitation + immunofluorescence & Zafar et al. (2011) \\
\hline $\begin{array}{l}\text { HS-1 associated protein } \\
\mathrm{X}-1(\mathrm{HAX}-1)\end{array}$ & Yeast two-hybrid system & Jing et al. (2011) \\
\hline Histone H1 & Far Western immunoblotting & Strom et al. (2011) \\
\hline Histone H3 & Far Western immunoblotting & Strom et al. (2011) \\
\hline Lamin B1 & Far Western immunoblotting & Strom et al. (2011) \\
\hline 14-3-3beta protein & Immunoprecipitation + pull-down assays & Liu et al. (2010) \\
\hline Casein kinase II & Immunoprecipitation + pull-down assays & Chen et al. (2008) \\
\hline Tetraspanin-7 & $\begin{array}{l}\text { Yeast two-hybrid } \\
\text { system + immunoprecipitation }\end{array}$ & Guo et al. (2008) \\
\hline $\begin{array}{l}\text { 2P domain } \mathrm{K}+\text { channel } \\
\text { TREK-1 protein }\end{array}$ & Bacterial two-hybrid + immunoprecipitation & Azzalin et al. (2006) \\
\hline ADAM23 & Immunoprecipitation + pull-down assay & Costa et al. (2009) \\
\hline
\end{tabular}

(Kurschner et al., 1995; Kuwahara et al., 1999). Prevention of cell death in cultured retinal explants from neonatal rats and mice induced by anisomysin (a protein synthesis inhibitor) unfurls and the effect is associated with PrP ${ }^{\mathrm{C}}$-STI1 interactions (Zanata et al., 2002). The production of another type of heat-shock protein (Hsp 70) is enhanced when PrP levels elevate during hyperglycaemia (Shyu et al., 2005). According to findings in another study, the inhibition of apoptosis through STI1 is mediated by $\operatorname{PrP}^{\mathrm{C}}$-dependent SOD activation (Sakudo et al., 2005). The functional role of STI1 and $\mathrm{PrP}^{\mathrm{C}}$ has been confirmed in both murine and bovine systems (Hashimoto et al., 2000). The late onset of severe ataxia and loss of cerebellar Purkinje cells in several knockout mouse lines (Moore et al., 1999; Rossi et al., 2001; Sakaguchi et al., 1996) suggest a lack of protection of cerebellum by $\mathrm{PrP}^{\mathrm{C}}$ in these mice. Interestingly, deposition of $\mathrm{PrP}^{\mathrm{Sc}}$ has been located in the deep cerebellar nuclei (DCN) of scrapie-infected sheep (Ersdal et al., 2003). Future studies with a microarray analysis (Park et al., 2006) applied in eye-blink conditioning of mice may provide insight into understanding the normal function of $\mathrm{PrP}^{\mathrm{C}}$ in the $\mathrm{DCN}$ of cerebellum.

A loss of $\mathrm{PrP}^{\mathrm{C}}$ function could be implicated in the pathogenesis of prion diseases and $\mathrm{PrP}^{\mathrm{C}}$-dependent pathways might be involved in neurotoxic signalling. For example, in vivo crosslinking of $\mathrm{PrP}^{\mathrm{C}}$ by antibodies triggered neuronal apoptosis (Solforosi et al., 2004) and $\mathrm{PrP}^{\mathrm{C}}$-dependent receptors were postulated to explain the neurotoxic effect of a PrP mutant lacking the hydrophobic domain (see next sections) (Winklhofer et al., 2008).

Taken together, $\mathrm{PrP}^{\mathrm{C}}$ is functionally involved in copper metabolism, signal transduction, neuroprotection and cell maturation (Fig. 2.1). Despite these published roles, mice that 


\section{Gain of function}

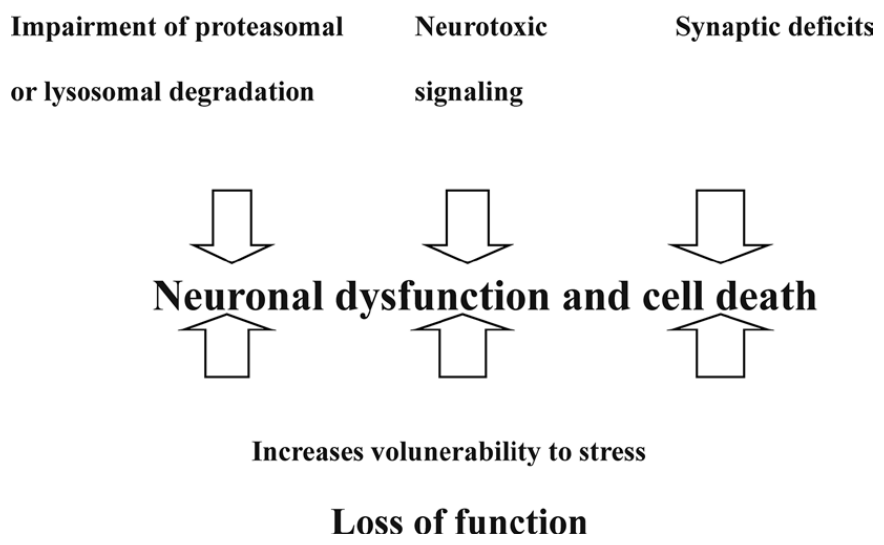

Figure 2.1 Gain and loss of function in prion disease.

are lacking $\mathrm{PrP}^{\mathrm{C}}$ display no consistent phenotype apart from complete resistance to TSE infection (Büeler et al., 1992, 1993). Further search for $\mathrm{PrP}^{\mathrm{C}}$-interaction molecules using $\mathrm{Prnp}^{-/-}$mice and various types of $\mathrm{Prnp}^{-/-}$cell lines under various conditions may elucidate the $\operatorname{PrP}^{\mathrm{C}}$ functions.

\section{Synaptic plasticity}

In $\mathrm{PrP}^{-/-}$mice, Kim et al. (2007) have observed pathological alterations and some physiological dysfunctions in olfactory bulb (OB). Recently, Le Pichen et al. (2009) have uncovered a significant phenotype of $\mathrm{PrP}^{-/-}$mice in the olfactory system by utilizing a combination of genetic, behavioural and physiological and physiological techniques in a systems approach. They employed a so-called 'cookie finding task', a test of broad olfactory acuity, to analyse a battery of mice including PrP knockout on multiple genetic backgrounds and transgenic mice in which Prnp expression was driven by cell type-specific promoters. $\mathrm{PrP}^{-/-}$mice exhibited impaired behaviour that was rescued in transgenic mice expressing $\operatorname{PrP}^{\mathrm{C}}$ specifically in neurons but not in mice expressing only extra-neuronal $\operatorname{PrP}^{\mathrm{C}} \cdot \operatorname{PrP}^{-/-}$mice displayed altered behaviour in an additional olfactory test (habituation-dishabituation) which was also rescued by transgenic neuronal $\operatorname{PrP}$ expression suggesting that the phenotype was olfactory specific.

Besides, the odour-evoked electrophysiological properties of the OB of PrP knockouts were studied (Le Pichon et al., 2009). In these mice, alterations in the patterns of oscillatory activity in the $\mathrm{OB}$ were detected. The plasticity of dendrodendritic synaptic transmission was altered between granule cells and mitral cell. Le Pichon et al. propose that electrophysiological alterations at the dendrodendritic synapse in the $\mathrm{OB}$ could underlie the behaviour phenotypes.

In detail, the cookie finding phenotype was manifest in three $\mathrm{PrP}^{-/-}$lines (Zurich I PrP knockout: Beuler et al., 1992; Nagasaki PrP knockout: Sakaguchi et al., 1996; Edinburgh PrP knockout: Manson et al., 1994) on alternate genetic backgrounds, indicating strong evidence of its dependence on $\mathrm{PrP}^{\mathrm{C}}$ rather than other genetic factors. PrP knockouts also displayed altered behaviour in the habituation-dishabituation task, suggesting the phenotype 
was likely olfactory-specific. $\mathrm{PrP}^{-/-}$mice exhibited wide spread alterations of oscillatory activity in the $\mathrm{OB}$ as well as altered paired-pulse plasticity at the dendrodendritic synapse. Both the behavioural and electrophysiological phenotypes were rescued by neuronal $\operatorname{PrP}^{\mathrm{C}}$ expression.

Disruption was observed in local field potential (LFP) oscillation and in the plasticity of the dendrodendritic synapse, either, or both, of which could contribute to the $\mathrm{PrP}^{-/-}$ behavioural phenotype. Oscillatory LFPs may act to organize information flow within the olfactory system (Lledo et al., 2006; Stopher et al., 2007) by constraining the timing of mitral cell action potentials (Kasiwadani et al., 1999). In addition, gamma oscillations are specifically implicated in behavioural performance in olfactory tasks (Beshel et al., 2007; Brown et al., 2005; Nusser et al., 2001). Therefore, alterations in oscillatory timing during odour exposure may perturb $\mathrm{OB}$ output to higher centres by disrupting how information is packaged within a breathing cycle.

Altering the dendrodendritic synapse may have multiple functional consequence. This synapse may mediate lateral inhibition between ensembles of mitral cells, and be critical for olfactory discrimination (Urban, 2002; Yokoi et al., 1995). Additionally, because granule cells receive convergent information onto their proximal dendritic arbour from multiple higher brain areas (Shepherd, 2003), disruption of the dendrodendritic synapse may alter the transmission of centrifugal modulation of $\mathrm{OB}$ mitral cells.

High frequency oscillations in the $\mathrm{OB}$ (gamma and high-gamma) are shown in vitro to result from the rapid and reciprocal interactions between granule and mitral cells across the dendrodendritic synapse (Lagier et al., 2007; Schoppa et al., 2006). Therefore, Le Picheon's observation could imply that increased facilitation of mitral cell inhibitory postsynaptic potential (IPSP) following repetitive spiking, decreases the dynamic range and increases the duration of gamma oscillations across the boundaries of breath. Although both oscillatory and synaptic effects could be reversed by neuronal $\operatorname{PrP}^{\mathrm{C}}$ expression, they cannot claim a causal link between these findings.

Mitral cells receive facilitated inhibition in $\mathrm{PrP}^{-/-}$mice. This facilitation could result from either pre- and/or post-synaptic changes to the dendrodendritic synapse. Future work should determine the precise synaptic localization of the $\mathrm{PrP}^{\mathrm{C}}$ protein as well as its biochemical interactions with synaptic machinery (Criado et al., 2005).

\section{Myelination and chronic demyelinating polyneuropathy}

A late-onset peripheral neuropathy has been identified in $\mathrm{PrP}^{\mathrm{C}}$-deficient Nagasaki (Prnp ${ }^{\text {Ngsk/ }}$ Ngsk) and Zurich-I (Prnp ${ }^{-/}$) mice (Sakaguchi et al., 1996; Nishida et al., 1999; Büeler et al., 1992). This indicates that $\operatorname{PrP}^{\mathrm{C}}$ might have a role in peripheral neuropathies. At 60 weeks of age, all $\mathrm{Prnp}^{-/-}$mice $(n=52)$ investigated showed chronic demyelinating polyneuropathy (CDP) (Bremer et al., 2010). CDP was 100\% penetrant and conspicuous in all investigated peripheral nerves (sciatic and trigeminal nerves, dorsal and ventral spinal roots). Besides, CDP was associated with another two independently targeted Prnp knockout mouse lines,

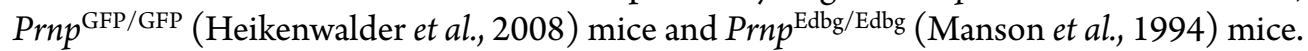

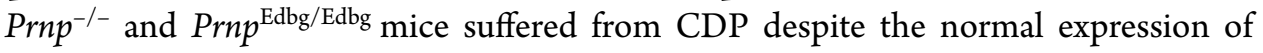
Doppel (Dpl) (Moore et al., 1999), indicating that Dpl regulation did not cause polyneuropathy. CDP was present in mice lacking both Prnp and Prnd (the gene for Dpl) (Genoud et al., 2004), but absent from mice selectively lacking Prnd (Behrens et al., 2002). Therefore, $\mathrm{Dpl}$ is not required for the maintenance of peripheral nerves. $\mathrm{PrP}^{\mathrm{C}}$ might interact with the 
myelin component directly or through other axonal proteins. Some of the reported $\mathrm{PrP}^{\mathrm{C}}$ interacting proteins have roles in homeostasis (Rutinshauser et al., 2009), and represent possible candidates for mediation of its myelinotrophic effects. The octapeptide repeat region was not required for myelin maintenance, whereas mice PrP lacking central domain (aa 94-134) developed CDP (Baumann et al., 2007). The hydrophobic core, but not the charge cluster $\left(\mathrm{CC}_{2}\right)$, of this central $\mathrm{PrP}^{\mathrm{C}}$ domain was essential for peripheral myelin maintenance.

$\mathrm{PrP}^{\mathrm{C}}$ undergoes regulated proteolysis in late secretory compartments (McMahon et al., 2001; Sunyach et al., 2007; Walmsley et al., 2009; Watt et al., 2005). Bremer et al. (2010) observed an association between the presence of CDP and lack of $\mathrm{C} 1$ fragment in sciatic nerves. All PrP mutants in which CDP was rescued produced abundant C1. Cleavage of $\mathrm{PrP}^{\mathrm{C}}$ appeared, therefore, to be linked to its myelinotrophic function. This conjuncture might also explain the requirement for membrane anchoring of $\mathrm{PrP}^{\mathrm{C}}$ uncovered in mice (Chesebro et al., 2005), as anchorless $\mathrm{PrP}^{\mathrm{C}}$ did not undergo regulated proteolysis.

Prion diseases mainly affect the central nervous system (CNS), myelin degeneration in optic nerves, corpus callosum or spinal cords was not detected in 60-week-old Prnp-/mice (Bremer et al., 2010). Nevertheless, subliminal myelin pathologies might extend to central myelin in $P_{r n p^{0 / 0}}$ mice (Nazor et al., 2007), and transgenic mice expressing toxic $\mathrm{PrP}^{\mathrm{C}}$ show both peripheral and central myelinopathy (Baumann et al., 2007; Radovanovic et al., 2005). $\operatorname{PrP}^{\mathrm{C}}$ deficiency affected synaptic function (Collinge et al., 1994; Mallucci et al., 2002). However, the amplitudes of foot muscle compound action potentials following distal stimulation were not significantly altered in 53-week-old $\mathrm{Prnp}^{0 / 0}$ mice thus arguing against an important synaptic defect in neuromuscular synaptic junction.

$\mathrm{PrP}^{\mathrm{C}}$ show various roles in immunity (Isaacs et al., 2006), and lymphocytes are important in mouse models of hereditary demyelinating neuropathies. As the CDP in our mutant mice was not modulated by removal of Rag1, lymphocytes are not involved in its pathogenesis. The combined results of restricting expression of $\mathrm{PrP}^{\mathrm{C}}$ of neurons and of selectively depleting $\operatorname{PrP}^{\mathrm{C}}$ from neurons indicate that the expression of $\operatorname{PrP}^{\mathrm{C}}$ by the neuron is essential for the long-term integrity of peripheral myelin sheaths (Bremer et al., 2010). Not only was the trophic function of $\mathrm{PrP}^{\mathrm{C}}$ exerted in trans, but also correlated with the proteolytic processing of in diverse transgenic mouse models. These findings identify $\operatorname{PrP}^{\mathrm{C}}$ as a critical messenger of transcellular axomyelinic communication and indicate that regulated proteolysis of axonal $\mathrm{PrP}^{\mathrm{C}}$ might exposed domains that interact with Schwann cell receptors. Clarifying the molecular basis of these phenomena might lead to a better understanding of peripheral neuropathies - particularly those of late onset - and might help to uncover new therapeutic targets.

Recent reports show that $\operatorname{PrP}^{\mathrm{C}}$-deficient mice of five different $\operatorname{PrP}^{\mathrm{C}}$-knockout strains, including the Prnp ${ }^{\mathrm{ZH} 3 / \mathrm{ZH} 3}$ mice (co-isogenic to $\mathrm{BL} / 6$ mice), develop a late-onset peripheral neuropathy, indicating that peripheral myelin maintenance is a bona fide physiological function of $\operatorname{PrP}^{\mathrm{C}}$ (Bremer et al., 2010; Nishida et al., 1999; Wulf et al., 2017). Nuvolone et al. (2016) used TALEN-mediated genomic editing in fertilized mouse oocytes to create Prnp ${ }^{\mathrm{ZH} 3 / \mathrm{ZH} 3}$ mice on a pure genetic C57BL/6J background. Genomic, translational and phenotypic characterization of $\mathrm{Prnp}^{\mathrm{ZH} 3 / \mathrm{ZH} 3}$ mice failed to identify phenotypes previously described in non-co-isogenic Prnp ${ }^{-/-}$mice. However, Prnp ${ }^{\mathrm{ZH} 3 / \mathrm{ZH} 3}$ mice developed a CDP, confirming the crucial involvement of $\operatorname{PrP}^{\mathrm{C}}$ in peripheral myelin maintenance.

Neuronal $\mathrm{PrP}^{\mathrm{C}}$ expression and amino-proximal cleavage are necessary for the promyelinating signal (Bremer et al., 2010). It has been discovered that very $\mathrm{N}$-terminal polycationic 
cluster of $\mathrm{PrP}^{\mathrm{C}}$ binds to the G-protein-coupled receptor Adgrg6 (Gpr126) of Schwann cells, eliciting a promyelinating cAMP response in vitro and in vivo in mice and zebrafish (Küffer et al., 2016). This pointed to the $\mathrm{N}$-terminal fragment of $\mathrm{PrP}^{\mathrm{C}}$ as a promyelinating factor that might serve as a possible treatment in other peripheral chronic demyelinating polyneuropathies (Wulf et al., 2017).

\section{$\mathrm{PrP}^{\mathrm{C}}$ mediates toxic signalling by PrPSc}

Mice with prion disease show misfolded PrP accumulation and developed extensive neurodegeneration, in contrast to mouse models of Alzheimer's disease (AD) or Parkinson's disease (PD), in which neuronal loss is rare. Therefore, prion-infected mice allow access to mechanism linking protein misfolding to neuronal death. Mallicci's group have previously shown the rescue of neuronal loss and the reversal of early cognitive and morphological changes in prion-infected mice by depleting $\operatorname{PrP}$ in neurons, preventing prion replication and abrogating neurotoxicity (Mallucci et al., 2003, 2007; White et al., 2008). The same group have shown that $\mathrm{PrP}^{\mathrm{Sc}}$ replication causes sustained unfolded protein response (UPR) induction with persistent, deleterious expression of eLF2 $\alpha-P$ in prion disease (Moreno et al., 2012). The resulting chronic blockade of protein synthesis leads to synaptic failure, spongiosis and neuronal loss. Promoting eLF2 $\alpha$-P dephosphorylation rescues vital translation rates and is thereby neuroprotective, whereas preventing this further reduces translation and enhances neurotoxicity. The data support the development of generic proteostatic approaches to therapy in prion (Balch et al., 2008; Tsaytler et al., 2011). The unfolded $\operatorname{PrP}^{\mathrm{C}}$ response works as protective cellular mechanism triggered by rising levels of misfolded $\mathrm{PrP}^{\mathrm{Sc}}$ protein (Moreno et al., 2012).

In another study, expression of $\mathrm{PrP}^{\mathrm{C}}$ in neuronal cells is required to mediate neurotoxic effects of $\mathrm{PrP}^{\mathrm{Sc}}$ (Chesebro et al., 2005). $\mathrm{PrP}^{\mathrm{Sc}}$ might elicit a deadly signal through a $\mathrm{PrP}^{\mathrm{C}}$ dependent signalling pathway. Spontaneous neurodegeneration in transgenic mice expressing a PrP mutant without the N-terminal endoplasmic reticulum (ER)-targeting sequence indicated a toxic potential of PrP when located in cytosolic compartment (cytoPrP) ( $\mathrm{Ma}$ et al., 2002). Toxicity of cytoPrP seems to be dependent on its association with cellular membranes (Wang et al., 2006) and its binding to Bcl-2, an antiapoptotic protein present at the cytosolic side of ER and mitochondrial membranes (Rambold et al., 2006). Might the toxic potential of misfolded $\mathrm{PrP}$ in the cytosol be relevant to the pathogenesis of prion diseases? Most recent information revealed an impairment of the ubiquitin-proteasome system (UPS) in prion-infected mice. In conjunction with in vitro and cell culture approaches, it was proposed that prion neurotoxicity is linked to $\mathrm{PrP}^{\mathrm{Sc}}$ oligomers, which translocate to the cytosol and inhibit the URS (Kristiansen et al., 2007).

\section{Stress-inducible and toxic signalling mediated by $\operatorname{PrP}^{\mathrm{C}}$ are interconnected}

$\operatorname{PrP}^{\mathrm{C}}$ expression is indispensable for prion-induced neurotoxicity (Brandner et al., 1996), implying that $\mathrm{PrP}^{\mathrm{C}}$ could be a receptor for prions to trigger detrimental signalling. Strittmatter reported that $\mathrm{PrP}^{\mathrm{C}}$ transduces the synaptic cytotoxicity of amyloid- $\beta(\mathrm{A} \beta)$ oligomers in vitro (Laurén et al., 2009) and in A $\beta$ transgenic mice (Gimbel et al., 2010). Moreover, different anti-PrP antibodies or their antigen-binding fragment that disrupt the $\operatorname{PrP}-\mathrm{A} \beta$ 
interaction were able to block the $A \beta$-mediated disruption of synaptic plasticity. These findings were important because they suggest the involvement of $\mathrm{PrP}^{\mathrm{C}}$ in Alzheimer's disease $(\mathrm{AD})$ pathogenesis. However, others found that the absence of $\mathrm{PrP}^{\mathrm{C}} \operatorname{did}$ not prevent deficits in hippocampal-dependent behavioural tests on intracerebral A $\beta$ injection (Balducci et al., 2010). Variations in copper availability could contribute to these discrepancies (Stys et al., 2012).

Parkin et al. (2007) reported an interaction between $\operatorname{PrP}^{\mathrm{C}}$ and the rate-limiting enzyme in the production of $\mathrm{A} \beta$, the $\beta$-secretase $\mathrm{BACE} 1$, and two studies have also found direct links: $\operatorname{PrP}^{C}$ has been reported to be a receptor for $A \beta$ oligomers (Laurén et al., 2009) and the expression of $\operatorname{PrP}^{\mathrm{C}}$ is controlled by the amyloid intracellular domain (AICD) (Vincent et al., 2009). There are two potential roles suggested for $\mathrm{PrP}^{\mathrm{C}}$ in $\mathrm{AD}$ : one, a role in the physiological regulation of amyloid precursor protein (APP) via interaction with $\mathrm{BACE} 1$; and two, a role in the pathological progression of $\mathrm{AD}$ by mediating $\mathrm{A} \beta$ toxicity by binding A $\beta 42$-oligomers. The feedback loop between, $\operatorname{PrP}^{\mathrm{C}}, \mathrm{BACE} 1, \mathrm{APP}$ and AICD are described, and provides a model linking these recent observations (Kellett et al., 2009). However, several questions remain to be answered, including, what effect does $A \beta 42$-oligomer binding have on the functions of $\operatorname{PrP}^{\mathrm{C}}$, how do the levels of $\operatorname{PrP}^{\mathrm{C}}$ compare with the brains of $\mathrm{AD}$ patients and age-matched control, and what is the effect of altering $\mathrm{PrP}^{\mathrm{C}}$ levels in mouse models of $\mathrm{AD}$. Understanding the molecular and cellular mechanisms involved in the interactions between $\operatorname{PrP}^{\mathrm{C}}$ and $\mathrm{APP} / \mathrm{A} \beta$ is crucial to the understanding of $\mathrm{AD}$ pathogenesis.

$\operatorname{PrP}^{\mathrm{C}}$ seems to regulate the $\beta$-secretase cleavage of amyloid precursor protein, thereby regulating the production of A $\beta$ (Parkin et al., 2007). Besides $\alpha$-secretase regulates the cleavage of $\mathrm{PrP}^{\mathrm{C}}$, regulating an $\mathrm{N}$-terminal fragment with neuroprotective activity (Cissé et al., 2005; Guillot-Sestier, et al., 2009). $\mathrm{PrP}^{\mathrm{C}}$ also binds to transmembrane proteins such as the $67-\mathrm{kDa}$ laminin receptor (Rieger et al., 1997; Gauczynski et al., 2001; Hundt et al., 2001), neural cell adhesion molecules (Schmitt-Ulms et al., 2001; Santuccione et al., 2005), G proteincoupled serotonergic receptors (Mouillet-Richard et al., 2005), and low density lipoprotein receptor-related protein 1 (Taylor et al., 2007; Parkyn et al., 2008), which are able to promote intracellular signalling-mediated neuronal adhesion and differentiation as well as $\mathrm{PrP}^{\mathrm{C}}$ internalization. Remarkably, $\mathrm{PrP}^{\mathrm{C}}$ functions as receptor or co-receptor for extracellular matrix proteins such as laminin (Graner et al., 2000a, 2000b) and vitronectin (Hajj et al., 2007), as well as STI1 (Zanata et al., 2002). These data suggest that glycosylphosphatidylinositolanchored $\mathrm{PrP}^{\mathrm{C}}$ is a possible scaffold receptor in a multiprotein, cell surface, signalling complex (Linden et al., 2008, 2009; Martins et al., 2010).

In hippocampal neurons STI1-PrP ${ }^{\mathrm{C}}$ engagement induces an increase in intracellular $\mathrm{Ca}^{2+}$ levels. Using a best candidate approach to test potential channels involved in $\mathrm{Ca}^{2+}$ influx, Beraldo et al. (2010) found that $\alpha$-bungarotoxin, a specific inhibitor for $\alpha 7$ nicotinic acetylcholine receptor $(\alpha 7 \mathrm{nAChR})$, was able to block $\mathrm{PrP}^{\mathrm{C}}-\mathrm{STI} 1$-mediated signalling, neuroprotection, and neuritogenesis. STI1 can interact with the $\operatorname{PrP}^{\mathrm{C}} \cdot \alpha 7 \mathrm{nAChR}$ complex to promote signalling and provide a potential target for modulation of the effect of prion protein in neurodegenerative diseases. The drugs that prevent bindings of $A \beta 1-42$ to $\alpha 7 \mathrm{nAChR}$ seem to be beneficial in a model of AD (Wang et al., 2009). It seems that STI1 binding to $\mathrm{PrP}^{\mathrm{C}}$ can hijack one of the key signalling pathways related to $\mathrm{AD}$. And it is possible that $\mathrm{STI} 1$ 
modulation containing a complex containing $\operatorname{PrP}^{\mathrm{C}}$ and $\alpha 7 \mathrm{nAChR}$ may play an important role in $\mathrm{AD}$.

Remarkably, $\operatorname{PrP}^{\mathrm{C}}$ functions as a receptor or coreceptor for extracellular matrix proteins such as laminin (Vassallo et al., 2005) and vitronectin (Hajj et al., 2007) as well as STI1(Sakudo et al., 2005), which has been repeatedly found by our group. These data suggest that GPI-anchored $\mathrm{PrP}^{\mathrm{C}}$ is a potential scaffold receptor protein, cell surface, and signalling complex. These processes may serve as the basis for the multiple neuronal functions ascribed to $\operatorname{PrP}^{\mathrm{C}}$ (Linden et al., 2008; Martin et al., 2010). $\mathrm{PrP}^{\mathrm{C}}$ has been identified to bind $\mathrm{A} \beta$ oligomers $(\mathrm{A} \beta \mathrm{O})$ with high affinity and to selectively interact with high molecular mass assembles of $\mathrm{A} \beta \mathrm{O}$ in $\mathrm{AD}$ but not control brains (Jarosz-Griffiths et al., 2016). $\operatorname{PrP}^{\mathrm{C}}$ is responsible for $\mathrm{A} \beta \mathrm{O}$-mediated inhibition of long-term potentiation (LTP) in hippocampal slices and is also required for the manifestation of memory impairment in an $\mathrm{AD}$ mouse model. $\mathrm{A} \beta \mathrm{O}$-binding to $\mathrm{PrP}^{\mathrm{C}}$ leads to activation of Fyn kinase. In addition, the $\mathrm{A} \beta \mathrm{O}$ activation of Fyn leads to phosphorylation of tau. Both metabotropic glutamate receptor 5 (mGluR5) and LPR1 have been identified as co-receptors required for the $\operatorname{PrP}^{\mathrm{C}}$-bound $\mathrm{A} \beta \mathrm{O}$ to activate Fyn (Jarosz-Griffiiths et al., 2016). Fyn kinase phosphorylates $N$-methyl-D-aspartate receptor (NMDAR) and tau. Eventually NMDAR and tau (pTyr18) induce synaptic impairment and neurodegeneration.

Recently, $A \beta 42$, which is associated with neurodegeneration in $A D$, has also been reported to act as a ligand of $\operatorname{PrP}^{\mathrm{C}}$ (Nah et al., 2013). Jung and our group have demonstrated that $\mathrm{PrP}^{\mathrm{C}}$ is critical in A 342 -mediated autophagy in neurons (Nah et al., 2013). The interaction of $\mathrm{PrP}^{\mathrm{C}}$ with Beclin $(\mathrm{BECN}) 1$ facilitates the localization of BECN1 into lipid rafts and thus allows the activation of phosphatidylinositol 3-kinase (catalytic subunit type-3 or $\mathrm{PI} 3 \mathrm{KC} 3$ ) complex in response to $\mathrm{A} \beta 42$, showing a beneficial role of $\mathrm{PrP}^{\mathrm{C}}$ as a positive regulator of the BECN1-PI3KC3 complex in lipid rafts (Fig. 2.2).

Several studies have reported that $\beta$-sheet-rich amyloid protein (including $\alpha$-synuclein)

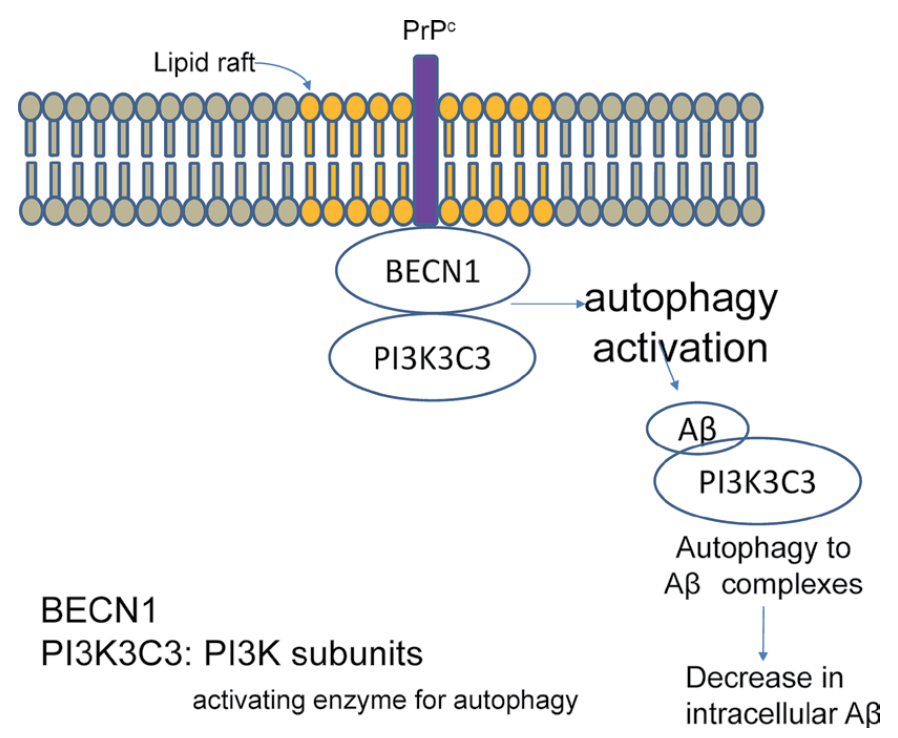

Figure 2.2 BECN1 (beclin 1) is supporting for intracellular decrease of $A \beta$. In elderly mice, the amount of cellular BECN1 is decreased. PI3K3C3 is a subunit of PI3K, and activating enzyme for autophagy to $A \beta$ complexes, working with BECN1. 
can interact with plasma membrane (Monsellier et al., 2016). Although this interaction might be involved in amyloid internalization leading to cytotoxicity, 'docking' receptor-mediated interaction activities at plasma membrane might support most of the physiological activities of the oligomeric proteinaceous species (Linden et al., 2017). $\mathrm{PrP}^{\mathrm{C}}$ can bind with numerous membrane-associated molecules including adhesion molecules, growth factor receptors, and neurotransmitter receptors, among others. Abnormal $\alpha$-synuclein aggregates appear, in addition to PD, in various $\alpha$-synucleinopathies such as dementia with Lewy bodies and multiple system atrophy (Masuda-Suzukake et al., 2014). In these disorders, aggregates are deposited in the brain in a filamentous form displaying a $\beta$-sheet structure (Serpell et al., 2000 ) which is abnormally phosphorylated at Serine129 ( $\alpha$-synuclein) and is also ubiquitinated (Urrea et al., 2017).

\section{Shadoo, a highly conserved glycoprotein with similarities to PrPC}

In the search for homologous/paralogues of $\mathrm{PrP}^{\mathrm{C}}$, a new gene was identified termed Sprn, encoding for a protein denoted Shadoo (Sho) (Premzl et al., 2003). Sho is highly conserved from fish to mammals. The sequence homology between Sho and $\mathrm{PrP}$ is restricted to the internal hydrophobic domain. However, certain features, such as a $\mathrm{N}$-terminal repeat region and a C-terminal glycosylphosphatidylinositol (GPI) anchor, are conserved, suggesting that Sho and PrP may be functionally related. Experimental evidence for the post-translational modifications and cell surface localization of Sho was first presented for zebrafish Sho (Miesbauer et al., 2006) and afterwards, also, for mouse Sho (Watts et al., 2007). Similarly to $\operatorname{PrP}^{\mathrm{C}}$, Sho can prevent neuronal cell death induced by the expression of PrP $\triangle \mathrm{HD}$ (hydrophobic domain) mutants, an artificial PrP mutant devoid of internal hydrophobic domain (Watts et al., 2007). The stress-protective activity of Sho is not restricted to counteracting the toxic effects of PrP $\Delta$ HD. Sakthivelu et al. (2011) employed glutamate as a physiologically relevant stressor to show Sho can efficiently protect cells against excitotoxin-induced cell death. Deletion mutants revealed that the stress-protective activity of Sho and PrP seems to be dependent on similar domains, in particular, the N-terminal and their internal hydrophobic domain. Sho $\Delta \mathrm{N}$ (N-terminal) and Sho $\Delta \mathrm{HD}$ displayed a reduced stress-protective activity but are complex glycosylated and attached to the outer leaflet of the plasma membrane via GPI anchor, indicating that the impaired activity is not due to incorrect cellular trafficking.

The N-terminal domain of $\mathrm{PrP}$ is intrinsically disordered, and these disordered domains are involved in protein-protein interactions (Tompa et al., 2009). Thus, it will be an attractive idea to assume that the $\mathrm{N}$-terminal domains of $\mathrm{PrP}^{\mathrm{C}}$ and Sho mediate interaction with an, as yet, unknown co-receptor required for intracellular signal transmission. The HD is the only domain with significant sequence homologies between Sho and $\operatorname{PrP}^{\mathrm{C}}$. The hydrophobic domain (HD) prompted dimerization of both Sho and $\mathrm{PrP}^{\mathrm{C}}$ and was part of dimer interface. It is worth mentioning that dimerization is a common feature of many cell surface receptors. Therefore, it can be speculated that dimer formation is involved in signal transmission of $\mathrm{PrP}^{\mathrm{C}}$ and Sho-dependent pathways. 


\section{Sho is stress-protective, however does not mediate PrPSc-induced toxicity}

Expression of murine Sho gene (Sprn) transgene significantly increased brain Sho protein levels in generated mice (Wang et al., 2011). Following infection with mouse-adapted scrapie strain 22L, all transgenic mice tested exhibited characteristics of scrapie disease. Importantly, there was no correlation between the expression level or incubation time of Sho with disease phenotypes. Although the function of Sho are, as yet, little characterized, the gain of function experiments seems to be essential for CNS development in mice. Wang et al. (2011) generated mice overexpressing Sho to determine the role of Sho in the pathogenesis of transmissible spongiform encephalopathy (TSE). Wang reported that Sho overexpression has no correlation with the incubation period of scrapie disease or with disease progression. There is no possible relationship between levels of Sho expression and scrapie pathology.

To evaluate the survival time, $22 \mathrm{~L}$ strain of scrapie was injected intracerebrally into the brains of wild-type and Sprn over-expressed mice with mouse PrP-promoter (TgMoSprn). All 16 prion-infected wild-type mice showed abnormal behaviour such as tremors and ataxia by 85 days. All mice had died by 149 days. The disease incubation period in infected wild-type mice was not significantly different from those of infected TgMoSprn mice; three lines totalled to 40 mice.

In Sho over-expressed transgenic mice, Wang et al. (2011) detected large amyloid plaques not seen in wild-type mice. Recent work has shown that reduction in levels of Sho was not a direct or simple consequence of $\mathrm{PrP}^{\mathrm{Sc}}$ accumulation. Instead, Sho protein levels are specific for the inoculated TSE agent and were not an intrinsic and invariant host process (Miyazawa and Manuelidis, 2010). Overexpression of Sho does not affect PrP, indicating that Sho has an alternate function. Other studies have shown that Sho exhibit no clear protective role in infected mice (Jeffrey et al., 1997; Lloyd et al., 2009; Miyazawa and Manuelidis, 2010) with no reduction in the time from incubation to neurological disease (Gossner et al., 2009). In $\operatorname{PrP}$ knockout-mouse brain there was no significant change in expression of Sho (Watts et al., 2007), further demonstrating that Sho protein and PrP protein are independent. The unaltered survival time of scrapie infected TgMoSprn mice is not in accordance with a neuroprotective effect of Sho, but it is not completely ruled out as there might be possible interference with a Sho-overexpressing phenotype. Anyway, Sho is not a major modulator of $\mathrm{PrP}^{\mathrm{Sc}}$ accumulation and scrapie pathogenesis.

\section{Sho mutants devoid of the internal hydrophobic domain do not acquire a toxic potential}

Studies in transgenic mice revealed the unexpected finding that $\operatorname{PrP}$ can acquire a neurotoxic potential by deleting the internal hydrophobic domain (Shmerling et al., 1998; Baumann et al., 2007; Li et al., 2007). The neurotoxic potential of PrP $\Delta \mathrm{HD}$ is independent of the propagation of infectious prions, a phenomenon also seen for other neurotoxic $\operatorname{PrP}$ mutants (Winklhofer et al., 2008). Although the underlying mechanism of PrP $\Delta \mathrm{HD}$ -induced toxicity are still elusive, co-expression of wild type $\operatorname{PrP}^{\mathrm{C}}$ completely prevents toxic effects of $\operatorname{PrP} \triangle \mathrm{HD}$. Based on this intriguing observation, it has been hypothesized that stress-protective signalling of $\operatorname{PrP}^{\mathrm{C}}$ and the neurotoxic signalling of $\operatorname{Pr} \mathrm{P} \Delta \mathrm{HD}$ are transmitted through a common co-receptor, which remains to be identified (Rambold et al., 2008; 
Shmerling et al., 1998; Baumann et al., 2007; Li et al., 2007). Co-transfection experiment with PrP-deficient cerebellar granule neurons indicated that Sho has a $\mathrm{PrP}^{\mathrm{C}}$-like activity to alleviate toxic effects of PrP $\Delta$ HD expression (Watts et al., 2007). Sakthivelu et al. (2011) have been able to recapitulate the toxic activity of $\operatorname{PrP} \Delta \mathrm{HD}$ expression in their cell culture model and demonstrate the protective activity of $\operatorname{PrP}$ and Sho against $\operatorname{PrP} \Delta \mathrm{HD}$-induced toxicity. In addition, Sakthivelu et al. (2011) showed that Sho $\Delta \mathrm{HD}$ lost its ability to protect against stress-induced cell death. However, Sho $\Delta \mathrm{HD}$ did not acquire a toxic activity, at least not under the experimental conditions tested. In summary, Sho and PrP share a stress-protective activity. However, the ability to adopt a toxic conformation seems to be specific for $\operatorname{PrP}$.

\section{Ablation of PrP in higher organism}

Any phenotypic effects of $\mathrm{PrP}^{\mathrm{C}}$ loss are readily studied in higher organisms. Cattle lacking PrP have been generated and apparently free of clinical physiological, pathological, immunological, and reproductive abnormalities, at least up to 20 months of age (Richt et al., 2007). PrP knockout goats have also been produced and appear to be developmentally normal (Yu et al., 2009).

Systemic lipopolysaccharide (LPS) challenge induced characteristic signs of sickness behaviour that was prolonged by about two hours in PrP-deficient $\left(\right.$ Prnp $\left.^{\text {Ter/Ter }}\right)$ goats after the initial dose of LPS (Salvesen et al., 2017). This is a noble clinical loss-of-function phenotype, pointing to a more inflammatory response in the absence of $\operatorname{PrP}^{\mathrm{C}}$. Transcriptome data revealed that in the absence of $\operatorname{PrP}^{\mathrm{C}}$, LPS induced an increased expression of numbers of genes downstream of type I interferons. It will be interesting to examine the peripheral nervous system in elderly knockout cows and goats to see if the role of $\mathrm{PrP}^{\mathrm{C}}$ in the maintenance of peripheral nerve myelination is conserved in higher organisms (Watts et al., 2018).

In humans, large-scale exome sequencing efforts have uncovered individuals carrying early stop codon mutations within one copy of their Prnp gene (Minikel et al., 2016). The location of these mutations predicts that only one functional copy of $\mathrm{PrP}^{\mathrm{C}}$ would be produced, and thus, these individuals would be expected to express approximately half of the normal level of $\mathrm{PrP}^{\mathrm{C}}$ in their brains. The limited phenotypic data available for these individuals, who are between the ages of 52 and 79, suggest the absence of any overt neurological diseases. More in-depth analysis of people who are partially or fully deficient for $\operatorname{PrP}^{\mathrm{C}}$ expression will be required to determine whether $\mathrm{PrP}^{\mathrm{C}}$ is also dispensable in humans.

\section{References}

Adle-Biassette, H., Verney, C., Peoc'h, K., Dauge, M.C., Razavi, F., Choudat, L., Gressens, P., Budka, H., and Henin, D. (2006). Immunohistochemical expression of prion protein $\left(\mathrm{PrP}^{\mathrm{C}}\right)$ in the human forebrain during development. J. Neuropathol. Exp. Neurol. 65, 698-706. https://doi.org/10.1097/01. jnen.0000228137.10531.72

Azzalin, A., Ferrara, V., Arias, A., Cerri, S., Avella, D., Pisu, M.B., Nano, R., Bernocchi, G., Ferretti, L., and Comincini, S. (2006). Interaction between the cellular prion $\left(\mathrm{PrP}^{\mathrm{C}}\right)$ and the $2 \mathrm{P}$ domain $\mathrm{K}^{+}$channel TREK-1 protein. Biochem. Biophys. Res. Commun. 346, 108-115.

Balch, W.E., Morimoto, R.I., Dillin, A., and Kelly,J.W. (2008). Adapting proteostasis for disease intervention. Science 319, 916-919. https://doi.org/10.1126/science.1141448

Balducci, C., Beeg, M., Stravalaci, M., Bastone, A., Sclip, A., Biasini, E., Tapella, L., Colombo, L., Manzoni, C., Borsello, T., et al. (2010). Synthetic amyloid-beta oligomers impair long-term memory independently of cellular prion protein. Proc. Natl. Acad. Sci. U.S.A. 107, 2295-300. https://doi.org/10.1073/ pnas.0911829107 
Baumann, F., Tolnay, M., Brabeck, C., Pahnke, J., Kloz, U., Niemann, H.H., Heikenwalder, M., Rülicke, T., Bürkle, A., and Aguzzi, A. (2007). Lethal recessive myelin toxicity of prion protein lacking its central domain. EMBO J. 26, 538-547.

Behrens, A., Genoud, N., Naumann, H., Rülicke, T., Janett, F., Heppner, F.L., Ledermann, B., and Aguzzi, A. (2002). Absence of the prion protein homologue Doppel causes male sterility. EMBO J. 21, 3652-8. https://doi.org/10.1093/emboj/cdf386

Beraldo, F.H., Arantes, C.P., Santos, T.G., Queiroz, N.G., Young, K., Rylett, R.J., Markus, R.P., Prado, M.A., and Martins, V.R. (2010). Role of $\alpha 7$ nicotinic acetylcholine receptor in calcium signaling induced by prion protein interaction with stress-inducible protein 1.J. Biol. Chem. 285, 36542-36550. https://doi. org/10.1074/jbc.M110.157263

Beshel, J., Kopell, N., and Kay, L.M. (2007). Olfactory bulb gamma oscillations are enhanced with task demands. J. Neurosci. 27, 8358-8365.

Bounhar, Y., Zhang, Y., Goodyer, C.G., and LeBlanc, A. (2001). Prion protein protects human neurons against Bax-mediated apoptosis. J. Biol. Chem. 276, 39145-39149. https://doi.org/10.1074/jbc. C100443200

Bragason, B.T., and Palsdottir, A. (2005). Interaction of PrP with NRAGE, a protein involved in neuronal apoptosis. Mol. Cell. Neurosci. 29, 232-244.

Brandner, S., Isenmann, S., Raeber, A., Fischer, M., Sailer, A., Kobayashi, Y., Marino, S., Weissmann, C., and Aguzzi, A. (1996). Normal host prion protein necessary for scrapie-induced neurotoxicity. Nature 379, 339-343. https://doi.org/10.1038/379339a0

Bremer, J., Baumann, F., Tiberi, C., Wessig, C., Fischer, H., Schwarz, P., Steele, A.D., Toyka, K.V., Nave, K.A., Weis, J., et al. (2010). Axonal prion protein is required for peripheral myelin maintenance. Nat. Neurosci. 13, 310-318. https://doi.org/10.1038/nn.2483

Brown, D.R. (1999). Prion protein expression aids cellular uptake and veratridine-induced release of copper. J. Neurosci. Res. 58, 717-725.

Brown, D.R., Qin, K., Herms, J.W., Madlung, A., Manson, J., Strome, R., Fraser, P.E., Kruck, T., von Bohlen, A., Schulz-Schaeffer, W., et al. (1997). The cellular prion protein binds copper in vivo. Nature 390, 684-687. https://doi.org/10.1038/37783

Brown, S.L., Joseph, J., and Stopfer, M. (2005). Encoding a temporally structured stimulus with a temporally structured neural representation. Nat. Neurosci. 8, 1568-7156.

Büeler, H., Fischer, M., Lang, Y., Bluethmann, H., Lipp, H.P., DeArmond, S.J., Prusiner, S.B., Aguet, M., and Weissmann, C. (1992). Normal development and behaviour of mice lacking the neuronal cell-surface PrP protein. Nature 356, 577-582. https://doi.org/10.1038/356577a0

Büeler, H., Aguzzi, A., Sailer, A., Greiner, R.A., Autenried, P., Aguet, M., and Weissmann, C. (1993). Mice devoid of PrP are resistant to scrapie. Cell 73, 1339-47.

Capellari, S., Zaidi, S.I., Urig, C.B., Perry, G., Smith, M.A., and Petersen, R.B. (1999). Prion protein glycosylation is sensitive to redox change. J. Biol. Chem. 274, 34846-34850.

Caughey, B.W., Dong, A., Bhat, K.S., Ernst, D., Hayes, S.F., and Caughey, W.S. (1991). Secondary structure analysis of the scrapie-associated protein PrP 27-30 in water by infrared spectroscopy. Biochemistry 30, $7672-7780$.

Chen, J., Gao, C., Shi, Q. Wang, G., Lei, Y., Shan, B., Zhang, B., Dong, C., Shi, S., Wang, X., et al. (2008). Casein kinase II interacts with prion protein in vitro and forms complex with native prion protein in vivo. Acta Biochim. Biophys. Sin. 40, 1039-1047.

Chesebro, B., Trifilo, M., Race, R., Meade-White, K., Teng, C., LaCasse, R., Raymond, L., Favara, C., Baron, G., Priola, S., et al. (2005). Anchorless prion protein results in infectious amyloid disease without clinical scrapie. Science 308, 1435-1439.

Cissé, M.A., Sunyach, C., Lefranc-Jullien, S., Postina, R., Vincent, B., and Checler, F. (2005). The disintegrin ADAM9 indirectly contributes to the physiological processing of cellular prion by modulating ADAM10 activity. J. Biol. Chem. 280, 40624-40631.

Collinge, J., Whittington, M.A., Sidle, K.C., Smith, C.J., Palmer, M.S., Clarke, A.R., and Jefferys, J.G. (1994). Prion protein is necessary for normal synaptic function. Nature 370, 295-297. https://doi. org/10.1038/370295a0

Costa, M.D., Paludo, K.S., Klassen, G., Lopes, M.H., Mercadante, A.F., Martins, V.R., Camargo, A.A., Nakao, L.S., and Zanata, S.M. (2009). Characterization of a specific interaction between ADAM23 and cellular prion protein. Neurosci. Lett. 461, 16-20. https://doi.org/10.1016/j.neulet.2009.05.049

Criado, J.R., Sánchez-Alavez, M., Conti, B., Giacchino, J.L., Wills, D.N., Henriksen, S.J., Race, R., Manson, J.C., Chesebro, B., and Oldstone, M.B. (2005). Mice devoid of prion protein have cognitive deficits that are rescued by reconstitution of PrP in neurons. Neurobiol. Dis. 19, 255-265. 
Edenhofer, F., Rieger, R., Famulok, M., Wendler, W., Weiss, S., and Winnacker, E.L. (1996). Prion protein PrPc interacts with molecular chaperones of the Hsp60 family. J. Virol. 70, 4724-4728.

Ersdal, C., Ulvund, M.J., Benestad, S.L., and Tranulis, M.A. (2003). Accumulation of pathogenic prion protein (PrPSc) in nervous and lymphoid tissues of sheep with subclinical scrapie. Vet. Pathol. 40, 164-174.

Gauczynski, S., Peyrin, J.M., Haïk, S., Leucht, C., Hundt, C., Rieger, R., Krasemann, S., Deslys, J.P., Dormont, D., Lasmézas, C.I., et al. (2001). The $37-\mathrm{kDa} / 67-\mathrm{kDa}$ laminin receptor acts as the cell-surface receptor for the cellular prion protein. EMBO J. 20, 5863-5875. https://doi.org/10.1093/emboj/20.21.5863

Genoud, N., Behrens, A., Miele, G., Robay, D., Heppner, F.L., Freigang, S., and Aguzzi, A. (2004). Disruption of Doppel prevents neurodegeneration in mice with extensive Prnp deletions. Proc. Natl. Acad. Sci. U.S.A. 101, 4198-4203. https://doi.org/10.1073/pnas.0400131101

Gimbel, D.A., Nygaard, H.B., Coffey, E.E., Gunther, E.G., Lauren, J., Gimbel, Z.A., and Strittmatter, S.M. (2010). Memory impairment in transgenic Alzheimer mice require cellular prion protein. J. Neurosci. $30,6367-6374$.

Gossner, A.G., Bennet, N., Hunter, N., and Hopkins, J. (2009). Differential expression of Prnp and Sprn in scrapie infected sheep also reveals Prnp genotype specific differences. Biochem. Biophys. Res. Commun. 378, 862-866. https://doi.org/10.1016/j.bbrc.2008.12.002

Graner, E., Mercadante, A.F., Zanata, S.M., Forlenza, O.V., Cabral, A.L., Veiga, S.S., Juliano, M.A., Roesler, R., Walz, R., Minetti, A., et al. (2000a). Cellular prion protein binds laminin and mediates neuritogenesis. Brain Res. Mol. Brain Res. 76, 85-92.

Graner, E., Mercadante, A.F., Zanata, S.M., Martins, V.R., Jay, D.G., and Brentani, R.R. (2000b). Laminin-induced PC-12 cell differentiation is inhibited following laser inactivation of cellular prion protein. FEBS Lett. 482, 257-260.

Guillot-Sestier,M.V.,Sunyach, C.,Druon, C.,Scarzello,S., and Checler,F.(2009). The alpha-secretase-derived $\mathrm{N}$-terminal product of cellular prion, $\mathrm{N} 1$, displays neuroprotective function in vitro and in vivo. J. Biol. Chem. 284, 35973-86. https://doi.org/10.1074/jbc.M109.051086

Guillot-Sestier, M.V., and Checler, F. (2012). Cellular prion and its catabolites in the brain: production and function. Curr. Mol. Med. 12, 304-215.

Guo, M., Huang, T., Cui, Y., Pan, B., Shen, A., Sun, Y., Yi, Y., Wang, Y., Xiao, G., and Sun, G. (2008). PrPC interacts with tetraspanin-7 through bovine PrP154-182 containing alpha-helix 1. Biochem. Biophys. Res. Commun. 365, 154-157.

Haigh, C.L., Edwards, K., and Brown, D.R. (2005). Copper binding is the governing determinant of prion protein turnover. Mol. Cell. Neurosci. 30, 186-196.

Hashimoto, A., Onodera, T., Ikeda, H., and Kitani, H. (2000). Isolation and characterisation of fetal bovine brain cells in primary culture. Res. Vet. Sci. 69, 39-46. https://doi.org/10.1053/rvsc.2000.0382

Hajj, G.N., Lopes, M.H., Mercadante, A.F., Veiga, S.S., da Silveira, R.B., Santos, T.G., Ribeiro, K.C., Juriano, M.A., Jacchieri, S.G., Zanata, S.M., and Martins, V.R. (2007). Cellular prion protein interaction with vitronectin supports axonal growth and is compensated by integrins. J. Cell Sci. 120, 1915-1926.

Heikenwalder, M., Kurrer, M.O., Margalith, I., Kranich, J., Zeller, N., Haybaeck, J., Polymenidou, M., Matter, M., Bremer, J., Jackson, W.S., et al. (2008). Lymphotoxin-dependent prion replication in inflammatory stromal cells of granulomas. Immunity 29, 998-1008. https://doi.org/10.1016/j.immuni.2008.10.014

Hornshaw, M.P., McDermott, J.R., and Candy, J.M. (1995). Copper binding to the N-terminal tandem repeat regions of mammalian and avian prion protein. Biochem. Biophys. Res. Commun. 207, 621-629.

Hoshino, S., Inoue, K., Yokoyama, T., Kobayashi, S., Asakura, T., Teramoto, A., and Itohara, S. (2003). Prions prevent brain damage after experimental brain injury: a preliminary report. Acta Neurochir. Suppl. 86, 297-299.

Huang, T., Xu, J., Xiang, J., Lu, Y., Chen, R., Huang, L., Xiao, G., and Sun, G. (2012). $\operatorname{PrP}^{\mathrm{C}}$ interacts with potassium channel tetramerization domain containing 1 (KCTD1) protein through the $\operatorname{PrP}(51-136)$ region containing octapeptide repeats. Biochem. Biophys. Res. Commun. 417, 182-186. https://doi. org/10.1016/j.bbrc.2011.11.081

Hundt, C., Peyrin, J.M., Haïk, S., Gauczynski, S., Leucht, C., Rieger, R., Riley, M.L., Deslys, J.P., Dormont, D., Lasmézas, C.I., et al. (2001). Identification of interaction domains of the prion protein with its $37-\mathrm{kDa} / 67-\mathrm{kDa}$ laminin receptor. EMBO J. 20, 5876-5886. https://doi.org/10.1093/ emboj/20.21.5876

Isaacs, J.D., Jackson, G.S., and Altmann, D.M. (2006). The role of the cellular prion protein in the immune system. Clin. Exp. Immunol. 146, 1-8.

Jarosz-Griffiths, H.H., Noble, E., Rushworth, J.V., and Hooper, N.M. (2016). Amyloid- $\beta$ receptors: The good, the bad, and the prion protein. J. Biol. Chem. 291, 3174-3183. https://doi.org/10.1074/jbc. R115.702704 
Jeffrey, M., Goodsir, C.M., Bruce, M.E., McBride, P.A., and Fraser, J.R. (1997). In vivo toxicity of prion protein in murine scrapie: ultrastructural and immunogold studies. Neuropathol. Appl. Neurobiol. 23, 93-101.

Jing, Y.Y., Li, X.L., Shi, Q. Wang, Z.Y., Guo, Y., Pan, M.M., Tian, C., Zhu, S.Y., Chen, C., Gong, H.S., et al. (2011). A novel PrP partner HS-1 associated protein X-1 (HAX-1) protected the cultured cells against the challenge of $\mathrm{H}_{2} \mathrm{O}_{2}$. J. Mol. Neurosci. 45, 216-228. https://doi.org/10.1007/s12031-011-9498-2

Kanaani, J., Prusiner, S.B., Diacovo, J., Baekkeskov, S., and Legname, G. (2005). Recombinant prion protein induces rapid polarization and development of synapses in embryonic rat hippocampal neurons in vitro. J. Neurochem. 95, 1373-1386.

Kashiwadani, H., Sasaki, Y.F., Uchida, N., and Mori, K. (1999). Synchronized oscillarory discharge of mitral/tufted cells with different molecular receptive ranges in the rabbit olfactory bulb. J. Neurophysiol. 82, 1786-1792.

Kellett, K.A., and Hooper, N.M. (2009). Prion protein and Alzheimer disease. Prion 3, 190-194.

Kramer, M.L., Kratzin, H.D., Schmidt, B., Römer, A., Windl, O., Liemann, S., Hornemann, S., and Kretzschmar, H. (2001). Prion protein binds copper within the physiological concentration range. J. Biol. Chem. 276, 16711-16719. https://doi.org/10.1074/jbc.M006554200

Keshet, G.I., Bar-Peled, O., Yaffe, D., Nudel, U., and Gabizon, R. (2000). The cellular prion protein colocalizes with the dystroglycan complex in the brain. J. Neurochem. 75, 1889-1897.

Kim, C.K., Sakudo, A., Taniuchi, Y., Kang, C.B., Lee, D.C., Saeki, K., Matsumoto, Y., Sakaguchi, S., Itohara, S., and Onodera, T. (2007). Abnormal olfactory function caused by ectopic expression of Doppel in the olfactory bulb of prion protein-deficient mice. Intl. J. Mol. Med. 20, 169-176.

Kretzschmar, H.A., Tings, T., Madlung, A., Giese, A., and Herms, J. (2000). Function of $\operatorname{PrP}(\mathrm{C})$ as a copper-binding protein at the synapse. Arch. Virol. Suppl. 16, 239-249.

Kristiansen, M., Deriziotis, P., Dimcheff, D.E., Jackson, G.S., Ovaa, H., Naumann, H., Clarke, A.R., van Leeuwen, F.W., Menéndez-Benito, V., Dantuma, N.P., et al. (2007). Disease-associated prion protein oligomers inhibit the $26 \mathrm{~S}$ proteasome. Mol. Cell 26, 175-188.

Kurschner, C., and Morgan, J.I. (1995). The cellular prion protein (PrP) selectively binds to Bcl-2 in the yeast two-hybrid system. Brain Res. Mol. Brain Res. 30, 165-168.

Kubosaki, A., Nishimura-Nasu, Y., Nishimura, T., Yusa, S., Sakudo, A., Saeki, K., Matsumoto, Y., Itohara, S., and Onodera, T. (2003). Expression of normal cellular prion protein $(\operatorname{PrP}(\mathrm{c}))$ on T lymphocytes and the effect of copper ion: Analysis by wild-type and prion protein gene-deficient mice. Biochem. Biophys. Res. Commun. 307, 810-813.

Küffer, A., Lakkaraju, A.K., Mogha, A., Petersen, S.C., Airich, K., Doucerain, C., Marpakwar, R., Bakirci, P., Senatore, A., Monnard, A., et al. (2016). The prion protein is an agonistic ligand of the G protein-coupled receptor Adgrg6. Nature 536, 464-468.

Kuwahara, C., Takeuchi, A.M., Nishimura, T., Haraguchi, K., Kubosaki, A., Matsumoto, Y., Saeki, K., Matsumoto, Y., Yokoyama, T., Itohara, S., et al. (1999). Prions prevent neuronal cell-line death. Nature 400, 225-226. https://doi.org/10.1038/22241

Lagier, S., Panzanelli, P., Russo, R.E., Nissant, A., Bathellier, B., Sassoè-Pognetto, M., Fritschy, J.M., and Lledo, P.M. (2007). GABAergic inhibition at dendrodendritic synapses tunes gamma oscillations in the olfactory bulb. Proc. Natl. Acad. Sci. U.S.A. 104, 7259-7264.

Lässle, M., Blatch, G.L., Kundra, V., Takatori, T., and Zetter, B.R. (1997). Stress-inducible, murine protein $\mathrm{mSTI1}$. Characterization of binding domains for heat shock proteins and in vitro phosphorylation by different kinases. J. Biol. Chem. 272, 1876-84.

Laurén, J., Gimbel, D.A., Nygaard, H.B., Gilbert, J.W., and Strittmatter, S.M. (2009). Cellular prion protein mediates impairment of synaptic plasticity by amyloid-beta oligomers. Nature 457, 1128-1132. https://doi.org/10.1038/nature07761

Le Pichon, C.E., Valley, M.T., Polymenidou, M., Chesler, A.T., Sagdullaev, B.T., Aguzzi, A., and Firestein, S. (2009). Olfactory behavior and physiology are disrupted in prion protein knockout mice. Nat. Neurosci. 12, 60-69. https://doi.org/10.1038/nn.2238

Li, A., Christensen, H.M., Stewart, L.R., Roth, K.A., Chiesa, R., and Harris, D.A. (2007). Neonatal lethality in transgenic mice expressing prion protein with a deletion of residues 105-125. EMBO J. 26, 548-558.

Linden, R., Martins, V.R., Prado, M.A., Cammarota, M., Izquierdo, I., and Brentani, R.R. (2008). Physiology of the prion protein. Physiol. Rev. 88, 673-728. https://doi.org/10.1152/physrev.00007.2007

Linden, R., Martins, V.R., and Prado, M.A. (2009). Prion protein. UCSD Nature Molecules Pages, 29.

Linden, R. (2017). The biological function of the prion protein: a cell surface scaffold of signaling modules. Front. Mol. Neurosci. 10, 77. https://doi.org/10.3389/fnmol.2017.00077 
Liu, Y.H., Han, Y.L., Song, J., Wang, Y., Zhou, W., Zhang, B.Y., Tian, C., Li, C.P., Han, J., and Dong, X.P. (2010). [Interaction between various 14-3-3beta segments and PrP in vitro.] Zhonghua Shi Yan He Lin Chuang Bing Du Xue Za Zhi 24, 165-167.

Lledo, P.M., and Lagier, S. (2006). Adjusting neurophysiological computations in the adult olfactory bulb. Semin. Cell Dev. Biol. 17, 443-453.

Lloyd, S.E., Grizenkova, J., Pota, H., and Collinge, J. (2009). Shadoo (Sprn) and prion disease incubation time in mice. Mamm. Genome 20, 367-374. https://doi.org/10.1007/s00335-009-9194-5

Lopes, M.H., Hajj, G.N., Muras, A.G., Mancini, G.L., Castro, R.M., Ribeiro, K.C., Brentani, R.R., Linden, R., and Martins, V.R. (2005). Interaction of cellular prion and stress-inducible protein 1 promotes neuritogenesis and neuroprotection by distinct signaling pathways. J. Neurosci. 25, 11330-11339.

Ma, J., Wollmann, R., and Lindquist, S. (2002). Neurotoxicity and neurodegeneration when PrP accumulates in the cytosol. Science 298, 1781-1785. https://doi.org/10.1126/science.1073725

Mallucci, G.R., Ratté, S., Asante, E.A., Linehan, J., Gowland, I., Jefferys, J.G., and Collinge, J. (2002). Post-natal knockout of prion protein alters hippocampal CA1 properties, but does not result in neurodegeneration. EMBO J. 21, 202-210. https://doi.org/10.1093/emboj/21.3.202

Mallucci, G., Dickenson, A., Linehan, J., Klohn, P.C., Brander, S., and Collinge, J. (2003). Depleting neonatal $\mathrm{PrP}$ in prion infection prevents disease and reverse spongiosis. Science 302, 871-874.

Mallucci, G.R., White, M.D., Farmer, M., Dickenson, A., Khatun, H., Powell, A.D., Brander, S., Jefferys, J.G., and Collinge, J. (2007). Targeting cellular prion protein reverses early congnitive deficits and neurophysiological dysfunction in prion-infected mice. Neuron 53, 325-335.

Mangé, A., Béranger, F., Peoc'h, K., Onodera, T., Frobert, Y., and Lehmann, S. (2004). Alpha- and beta- cleavages of the amino-terminus of the cellular prion protein. Biol. Cell 96, 125-132. https://doi. org/10.1016/j.biolcel.2003.11.007

Manson, J., West, J.D., Thomson, V., McBride, P., Kaufman, M.H., and Hope, J. (1992). The prion protein gene: a role in mouse embryogenesis? Development 115, 117-122.

Manson, J.C., Clarke, A.R., Hooper, M.L., Aitchison, L., McConnell, I., and Hope, J. (1994). 129/Ola mice carrying a null mutation in PrP that abolishes mRNA production are developmentally normal. Mol. Neurobiol. 8, 121-127. https://doi.org/10.1007/BF02780662

Martins, V.R., Graner, E., Garcia-Abreu, J., de Souza, S.J., Mercadante, A.F., Veiga, S.S., Zanata, S.M., Neto, V.M., and Brentani, R.R. (1997). Complementary hydropathy identifies a cellular prion protein receptor. Nat. Med. 3, 1376-1382.

Mattei, V., Garofalo, T., Misasi, R., Circella, A., Manganelli, V., Lucania, G., Pavan, A., and Sorice, M. (2004). Prion protein is a component of the multimolecular signaling complex involved in $\mathrm{T}$ cell activation. FEBS Lett. 560, 14-18. https://doi.org/10.1016/S0014-5793(04)00029-8

Martins, V.R., Beraldo, F.H., Hajj, G.N., Lopes, M.H., Lee, K.S., Prado, M.A., and Linden, R. (2010). Prion protein: orchestrating neurotrophic activities. Curr. Issues Mol. Biol. 12, 63-86.

Masuda-Suzukake, M., Nonaka, T., Hosokawa, M., Kubo, M., Shimozawa, A., Akiyama, H., and Hasegawa, M. (2014). Pathological alpha-synuclein propagates through neural networks. Acta Neuropathol. Commun. 2, 88. https://doi.org/10.1186/s40478-014-0088-8

McKinley, M.P., Taraboulos, A., Kenaga, L., Serban, D., Stieber, A., DeArmond, S.J., Prusiner, S.B., and Gonatas, N. (1991). Ultrastructural localization of scrapie prion protein in cytoplasmic vesicles of infected cultured cells. Lab. Invest. 65, 622-630.

McMahon, H.E., Mangé, A., Nishida, N., Créminon, C., Casanova, D., and Lehmann, S. (2001). Cleavage of the amino terminus of the prion protein by reactive oxygen species. J. Biol. Chem. 276, 2286-2291. https://doi.org/10.1074/jbc.M007243200

Meggio, F., Negro, A., Sarno, S., Ruzzene, M., Bertoli, A., Sorgato, M.C., and Pinna, L.A. (2000). Bovine prion protein as a modulator of protein kinase CK2. Biochem. J. 352, 191-196.

Miele, G., Alejo Blanco, A.R., Baybutt, H., Horvat, S., Manson, J., and Clinton, M. (2003). Embryonic activation and developmental expression of the murine prion protein gene. Gene Expr. 11, 1-12.

Miesbauer, M., Bamme, T., Riemer, C., Oidtmann, B., Winklhofer, K.F., Baier, M., and Tatzelt, J. (2006). Prion protein-related proteins from zebrafish are complex glycosylated and contain a glycosylphosphatidylinositol anchor. Biochem. Biophys. Res. Commun. 341, 218-224.

Minikel, E.V., Vallabh, S.M., Lek, M., Estrada, K., Samocha, K.E., Sathirapongsasuti, J.F., McLean, C.Y., Tung, J.Y., Yu, L.P., Gambetti, P., et al. (2016). Quantifying prion disease penetrance using large population control cohorts. Sci. Transl. Med. 8, 322ra9. https://doi.org/10.1126/scitranslmed.aad5169

Miura, T., Hori-i, A., Mototani, H., and Takeuchi, H. (1999). Raman spectroscopic study on the copper(II) binding mode of prion octapeptide and its $\mathrm{pH}$ dependence. Biochemistry 38, 11560-9. https://doi. org/10.1021/bi9909389 
Miyazawa, K., and Manuelidis, L. (2010). Agent-specific Shadoo responses in transmissible encephalopathies. J. Neuroimmune Pharmacol. 5, 155-63. https://doi.org/10.1007/s11481-0109191-1

Monsellier, E., Bousset, L., and Melki, R. (2016). $\alpha$-Synuclein and huntingtin exon 1 amyloid fibrils bind laterally to the cellular membrane. Sci. Rep. 6, 19180. https://doi.org/10.1038/srep19180

Moore, R.C., Lee, I.Y., Silverman, G.L., Harrison, P.M., Strome, R., Heinrich, C., Karunaratne, A., Pasternak, S.H., Chishti, M.A., Liang, Y., et al. (1999). Ataxia in prion protein (PrP)-deficient mice is associated with upregulation of the novel PrP-like protein doppel. J. Mol. Biol. 292, 797-817. https:// doi.org/10.1006/jmbi.1999.3108

Moreno, J.A., Radford, H., Peretti, D., Steinert, J.R., Verity, N., Martin, M.G., Halliday, M., Morgan, J., Dinsdale, D., Ortori, C.A., et al. (2012). Sustained translational repression by eIF2 $\alpha$-P mediates prion neurodegeneration. Nature 485, 507-511. https://doi.org/10.1038/nature11058

Mouillet-Richard, S., Ermonval, M., Chebassier, C., Laplanche, J.L., Lehmann, S., Launay, J.M., and Kellermann, O. (2000). Signal transduction through prion protein. Science 289, 1925-1928.

Mouillet-Richard, S., Pietri, M., Schneider, B., Vidal, C., Mutel, V., Launay, J.M., and Kellermann, O. (2005). Modulation of serotonergic receptor signaling and cross-talk by prion protein. J. Biol. Chem. $280,4592-4601$.

Nah, J., Pyo, J.O., Jung, S., Yoo, S.M., Kam, T.I., Chang, J., Han, J., Soo A An, S., Onodera, T., and Jung, Y.K. (2013). BECN1/Beclin 1 is recruited into lipid rafts by prion to activate autophagy in response to amyloid $\beta$ 42. Autophagy 9, 2009-2021.

Nazor, K.E., Seward, T., and Telling, G.C. (2007). Motor behavior and neuropathological deficits in mice deficient for normal prion protein expression. Biochim. Biophys. Acta 1772, 645-653.

Nieznanski, K., Nieznanska, H., Skowronek, K.J., Osiecka, K.M., and Stepkowski, D. (2005). Direct interaction between prion protein and tubulin. Biochem. Biophys. Res. Commun. 334, 403-411.

Nishida, N., Tremblay, P., Sugimoto, T., Shigematsu, K., Shirabe, S., Petromilli, C., Erpel, S.P., Nakaoke, R., Atarashi, R., Houtani, T., et al. (1999). A mouse prion protein transgene rescues mice deficient for the prion protein gene from purkinje cell degeneration and demyelination. Lab. Invest. 79, 689-697.

Nuvolone, M., Hermann, M., Sorce, S., Russo, G., Tiberi, C., Schwarz, P., Minikel, E., Sanoudou, D., Pelczar, P., and Aguzzi, A. (2016). Strictly co-isogenic C57BL/6J-Prnp ${ }^{-/-}$mice: a rigorous resource for prion science. J. Exp. Med. 213, 313-327. https://doi.org/10.1084/jem.20151610

Nusser, Z., Kay, L.M., Laurent, G., Homanics, G.E., and Mody, I. (2001). Disruption of GABA(A) receptors on GABAergic interneurons leads to increased oscillatory power in the olfactory bulb network. J. Neurophysiol. 86, 2823-2833. https://doi.org/10.1152/jn.2001.86.6.2823

Oesch, B., Teplow, D.B., Stahl, N., Serban, D., Hood, L.E., and Prusiner, S.B. (1990). Identification of cellular proteins binding to the scrapie prion protein. Biochemistry 29, 5848-5855.

Onodera, T., Sakudo, A., Tsubone, H., and Itohara, S. (2014). Review of studies that have used knockout mice to assess normal function of prion protein under immunological or pathophysiological stress. Microbiol. Immunol. 58, 361-374.

Pan, K.M., Baldwin, M., Nguyen, J., Gasset, M., Serban, A., Groth, D., Mehlhorn, I., Huang, Z., Fletterick, R.J., Cohen, F.E., and Prusiner, S.B. (1993). Conversion of alpha-helix into beta-sheets features in the formation of the scrapie prion proteins. Proc. Natl. Acad. Sci. U.S.A. 90, 10962-10966.

Park, J.S., Onodera, T., Nishimura, S., Thompson, R.F., and Itohara, S. (2006). Molecular evidence for two-stage learning and partial laterality in eyeblink conditioning of mice. Proc. Natl. Acad. Sci. U.S.A. 103, 5549-5554.

Parkin, E.T., Watt, N.T., Hussain, I., Eckman, E.A., Eckman, C.B., Manson, J.C., Baybutt, H.N., Turner, A.J., and Hooper, N.M. (2007). Cellular prion protein regulates beta-secretase cleavage of the Alzheimer's amyloid precursor protein. Proc. Natl. Acad. Sci. U.S.A. 104, 11062-11067.

Parkyn, C.J., Vermeulen, E.G., Mootoosamy, R.C., Sunyach, C., Lacobsen, C., Oxvig, C., Moestrup, S., Liu, Q. Bu, G., Jen, A., and Morris, R.J. (2008). LRP1 control biosynthetic and endocytic trafficking of neural prion protein. J. Cell Sci. 121, 773-783.

Pattison, I.H., and Jebbett, J.N. (1973). Clinical and histological recovery from the scrapie-like spongiform encephalopathy produced in mice by feeding them with cuprizone. J. Pathol. 109, 245-250. https:// doi.org/10.1002/path.1711090310

Pauly, P.C., and Harris, D.A. (1998). Copper stimulates endocytosis of the prion protein. J. Biol. Chem. 273, 33107-33110.

Peralta, O.A., Huckle, W.R., and Eyestone, W.H. (2011). Expression and knockdown of cellular prion protein $\left(\mathrm{PrP}^{\mathrm{C}}\right)$ in differentiating mouse embryonic stem cells. Differentiation $81,68-77$. https://doi. org/10.1016/j.diff.2010.09.181 
Premzl, M., Sangiorgio, L., Strumbo, B., Marshall Graves, J.A., Simonic, T., and Gready, J.E. (2003). Shadoo, a new protein highly conserved from fish to mammals and with similarity to prion protein. Gene 314 , 89-102.

Prusiner, S.B. (1997). Prion diseases and the BSE crisis. Science 278, 245-251.

Rambold, A.S., Miesbauer, M., Rapaport, D., Bartke, T., Baier, M., Winklhofer, K.F., and Tatzelt, J. (2006). Association of Bcl-2 with misfolded prion protein is linked to the toxic potential of cytosolic PrP. Mol. Biol. Cell 17, 3356-3368.

Rambold, A.S., Müller, V., Ron, U., Ben-Tal, N., Winklhofer, K.F., and Tatzelt, J. (2008). Stress-protective signalling of prion protein is corrupted by scrapie prions. EMBO J. 27, 1974-1984. https://doi. org/10.1038/emboj.2008.122

Radovanovic, I., Braun, N., Giger, O.T., Mertz, K., Miele, G., Prinz, M., Navarro, B., and Aguzzi, A. (2005). Truncated prion protein and Doppel are myelinotoxic in the absence of oligodendrocytic $\operatorname{PrP}^{\mathrm{C}} . \mathrm{J}$. Neurosci. 25, 4879-4888.

Richt, J.A., Kasinathan, P., Hamir, A.N., Castilla, J., Sathiyaseelan, T., Vargas, F., Sathiyaseelan, J., Wu, H., Matsushita, H., Koster, J., et al. (2007). Production of cattle lacking prion protein. Nat. Biotechnol. 25, $132-138$.

Rieger, R., Edenhofer, F., Lasmézas, C.I., and Weiss, S. (1997). The human 37-kDa laminin receptor precursor interacts with the prion protein in eukaryotic cells. Nat. Med. 3, 1383-1388.

Rossi, D., Cozzio, A., Flechsig, E., Klein, M.A., Rülicke, T., Aguzzi, A., and Weissmann, C. (2001). Onset of ataxia and Purkinje cell loss in PrP null mice inversely correlated with Dpl level in brain. EMBO J. 20, 694-702. https://doi.org/10.1093/emboj/20.4.694

Roucou, X., Giannopoulos, P.N., Zhang, Y., Jodoin, J., Goodyer, C.G., and LeBlanc, A. (2005). Cellular prion protein inhibits proapoptotic Bax conformational change in human neurons and in breast carcinoma MCF-7 cells. Cell Death Differ. 12, 783-795.

Rutishauser, D., Mertz, K.D., Moos, R., Brunner, E., Rülicke, T., Calella, A.M., and Aguzzi, A. (2009). The comprehensive native interactome of a fully functional tagged prion protein. PLOS ONE 4, e4446. https://doi.org/10.1371/journal.pone.0004446

Sakaguchi, S., Katamine, S., Nishida, N., Moriuchi, R., Shigematsu, K., Sugimoto, T., Nakatani, A., Kataoka, Y., Houtani, T., Shirabe, S., et al. (1996). Loss of cerebellar Purkinje cells in aged mice homozygous for a disrupted PrP gene. Nature 380, 528-531. https://doi.org/10.1038/380528a0

Sakthivelu, V., Seidel, R.P., Winklhofer, K.F., and Tatzelt, J. (2011). Conserved stress-protective activity between prion protein and Shadoo. J. Biol. Chem. 286, 8901-8908. https://doi.org/10.1074/jbc. M110.185470

Sakudo, A., Lee, D.C., Li, S., Nakamura, T., Matsumoto, Y., Saeki, K., Itohara, S., Ikuta, K., and Onodera, T. (2005). PrP cooperates with STI1 to regulate SOD activity in PrP-deficient neuronal cell line. Biochem. Biophys. Res. Commun. 328, 14-19.

Sakudo, A., Lee, D.C., Nishimura, T., Li, S., Tsuji, S., Nakamura, T., Matsumoto, Y., Saeki, K., Itohara, S., Ikuta, K., and Onodera, T. (2005). Octapeptide repeat region and N-terminal half of hydrophobic region of prion protein (PrP) mediates PrP-dependent activation of superoxide dusmutase. Biochem. Biophys. Res. Commun. 326, 600-606.

Sakudo, A., Onodera, T., Suganuma, Y., Kobayashi, T., Saeki, K., and Ikuta, K. (2006). Recent advances in clarifying prion protein functions using knockout mice and derived cell lines. Mini Rev. Med. Chem. 6, 589-601.

Salvesen, O., Reiten, M.R., Espenes, A., Bakkebo, M.K., Tranulis, M.A., and Ersdal, C. (2017). LPS-induced systemic inflammation reveals an immunomodulatory role for the prion protein at the blood-brain interface. J. Neuroinflamm. 14, 106.

Santuccione, A., Sytnyk, V., Leshchyns'ka, I., and Schachner, M. (2005). Prion protein recruits its neuronal receptor NCAM to lipid rafts to activate p59fyn and to enhance neurite outgrowth. J. Cell Biol. 169, 341-354.

Schmitt-Ulms, G., Legname, G., Baldwin, M.A., Ball, H.L., Bradon, N., Bosque, P.J., Crossin, K.L., Edelman, G.M., DeArmond, S.J., Cohen, F.E., et al. (2001). Binding of neural cell adhesion molecules (N-CAMs) to the cellular prion protein. J. Mol. Biol. 314, 1209-1225. https://doi.org/10.1006/jmbi.2000.5183

Schneider, B., Mutel, V., Pietri, M., Ermonval, M., Mouillet-Richard, S., and Kellermann, O. (2003). NADPH oxidase are extracellular regulated kinase $1 / 2$ are targets of prion protein signaling in neuronal and nonneuronal cells. Proc. Natl. Acad. Sci. U.S.A. 100, 13326-13331.

Schoppa, N.E. (2006). Synchronization of olfactory bulb mitral cells by precisely timed inhibitory inputs. Neuron 49, 271-283. 
Serpell, L.C., Berriman, J., Jakes, R., Goedert, M., and Crowther, R.A. (2000). Fiber diffraction of synthetic alphasynuclein filaments shows amyloid-like cross-beta conformation. Proc. Natl. Acad. Sci. U.S.A. 97, 4897-4902.

Shepherd, G.M. (2003). The Synaptic Organization of Brain (Oxford University Press; New York).

Shmerling, D., Hegyi, I., Fischer, M., Blättler, T., Brandner, S., Götz, J., Rülicke, T., Flechsig, E., Cozzio, A., von Mering, C., et al. (1998). Expression of amino-terminally truncated PrP in the mouse leading to ataxia and specific cerebellar lesions. Cell 93, 203-214.

Shyu, W.C., Chen, C.P., Saeki, K., Kubosaki, A., Matusmoto, Y., Onodera, T., Ding, D.C., Chiang, M.F., Lee, Y.J., Lin, S.Z., et al. (2005). Hypoglycemia enhances the expression of prion protein and heat-shock protein 70 in a mouse neuroblastoma cell line. J. Neurosci. Res. 80, 887-894. https://doi.org/10.1002/ jnr.20509

Solforosi, L., Criado, J.R., McGavern, D.B., Wirz, S., Sánchez-Alavez, M., Sugama, S., DeGiorgio, L.A., Volpe, B.T., Wiseman, E., Abalos, G., et al. (2004). Cross-linking cellular prion protein triggers neuronal apoptosis in vivo. Science 303, 1514-1516. https://doi.org/10.1126/science.1094273

Spielhaupter, C., and Schätzl, H.M. (2001). $\mathrm{PrP}^{\mathrm{C}}$ directly interacts with proteins involved in signaling pathways. J. Biol. Chem. 276, 44604-12. https://doi.org/10.1074/jbc.M103289200

Steele, A.D., Emsley, J.G., Ozdinler, P.H., Lindquist, S., and Macklis, J.D. (2006). Prion protein (PrPc) positively regulates neural precursor proliferation during developmental and adult mammalian neurogenesis. Proc. Natl. Acad. Sci. U.S.A. 103, 3416-3421.

Steele, A.D., Lindquist, S., and Aguzzi, A. (2007). The prion protein knockout mouse: a phenotype under challenge. Prion 1, 83-93.

Stopfer, M. (2007). Olfactory processing: massive convergence onto sparse codes. Curr. Biol. 17, R363364.

Strom, A., Wang, G.S., Picketts, D.J., Reimer, R., Stuke, A.W., and Scott, F.W. (2011). Cellular prion protein localizes to the nucleus of endocrine and neuronal cells and interacts with structural chromatin components. Eur. J. Cell Biol. 90, 414-419. https://doi.org/10.1016/j.ejcb.2010.11.015

Stys, P.K., You, H., and Zamponi, G.W. (2012). Copper-dependent regulation of NMDA receptors by cellular prion protein: implication for neurodegenerative disorders. J. Physiol. 590, 1357-1368.

Sunyach, C., Cisse, M.A., da Costa, C.A., Vincent, B., and Checler, F. (2007). The C-terminal products of cellular prion protein processing, $\mathrm{C} 1$ and $\mathrm{C} 2$, exert distinct influence on p53-dependent staurosporine-induced caspase-3 activation. J. Biol. Chem. 282, 1956-1963.

Tanji, K., Saeki, K., Matsumoto, Y., Takeda, M., Hirasawa, K., Doi, K., Matsumoto, Y., and Onodera, T. (1995). Analysis of PrPc mRNA by in situ hybridization in brain, placenta, uterus and testis of rats. Intervirology 38, 309-315. https://doi.org/10.1159/000150457

Taraboulos, A., Jendroska, K., Serban, D., Yang, S.L., DeArmond, S.J., and Prusiner, S.B. (1992). Regional mapping of prion proteins in brain. Proc. Natl. Acad. Sci. U.S.A. 89, 7620-7624.

Taylor, D.R., and Hooper, N.M. (2007). The low-density lipoprotein receptor-related protein 1 (LRP1) mediates the endocytosis of the cellular prion protein. Biochem. J. 402, 17-23.

Tompa, P., Fuxreiter, M., Oldfield, C.J., Simon, I., Dunker, A.K., and Uversky, V.N. (2009). Close encounters of the third kind: disordered domains and the interactions of proteins. Bioessays 31, 328-335. https:// doi.org/10.1002/bies.200800151

Tremblay, P., Bouzamondo-Bernstein, E., Heinrich, C., Prusiner, S.B., and DeArmond, S.J. (2007). Developmental expression of PrP in the post-implantation embryo. Brain Res. 1139, 60-67.

Tsaytler, P., Harding, H.P., Ron, D., and Bertolotti, A. (2011). Selective inhibition of a regulatory subunit of protein phosphatase 1 restores proteostasis. Science 332, 91-4. https://doi.org/10.1126/ science. 1201396

Urban, N.N. (2002). Lateral inhibition in the olfactory bulb and in olfaction. Physiol. Behav. 77, 607-612.

Urrea, L., Ferrer, I., Gavín, R., and Del Río, J.A. (2017). The cellular prion protein $\left(\operatorname{PrP}^{\mathrm{C}}\right)$ as neuronal receptor for $\alpha$-synuclein. Prion 11, 226-233. https://doi.org/10.1080/19336896.2017.1334748

Vassallo, N., and Herms, J. (2003). Cellular prion protein function in copper homeostasis and redox signalling at the synapse. J. Neurochem. 86, 538-544.

Vassallo, N., Herms, J., Behrens, C., Krebs, B., Saeki, K., Onodera, T., Windl, O., and Kretzschmar, H.A. (2005). Activation of phosphatidylinositol 3-kinase by cellular prion protein and its role in cell survival. Biochem. Biophys. Res. Commun. 332, 75-82.

Vincent, B., Sunyach, C., Orzechowski, H.D., St George-Hyslop, P., and Checler, F. (2009). p53-Dependent transcriptional control of cellular prion by presenilins. J. Neurosci. 29, 6752-6760. https://doi. org/10.1523/JNEUROSCI.0789-09.2009 
Walmsley, A.R., Watt, N.T., Taylor, D.R., Perera, W.S., and Hooper, N.M. (2009). alpha-cleavage of the prion protein occurs in a late compartment of the secretory pathway and is independent of lipid rafts. Mol. Cell. Neurosci. 40, 242-248. https://doi.org/10.1016/j.mcn.2008.10.012

Wang, H.Y., Stucky, A., Liu, J., Shen, C., Trocme-Thibierge, C., and Morain, P. (2009). Dissociating beta-amyloid from alpha 7 nicotinic acetylcholine receptor by a novel therapeutic agent, S 24795, normalizes alpha 7 nicotinic acetylcholine and NMDA receptor function in Alzheimer's disease brain. J. Neurosci. 29, 10961-10973. https://doi.org/10.1523/JNEUROSCI.6088-08.2009

Wang, H., Wan, J., Wang, W., Wang, D., Li, S., Liao, P., Hao, Z., Wu, S., Xu, J., Li, N., et al. (2011). Overexpression of Shadoo protein in transgenic mice does not impact the pathogenesis of scrapie. Neurosci. Lett. 496, 1-4. https://doi.org/10.1016/j.neulet.2011.03.073

Wang, X., Wang, F., Arterburn, L., Wollmann, R., and Ma, J. (2006). The interaction between cytoplasmic prion protein and the hydrophobic lipid core of membrane correlates with neurotoxicity. J. Biol. Chem. 281, 13559-13565.

Watarai, M., Kim, S., Erdenebaatar, J., Makino, S., Horiuchi, M., Shirahata, T., Sakaguchi, S., and Katamine, S. (2003). Cellular prion protein promotes Brucella infection into macrophages. J. Exp. Med. 198, 5-17. https://doi.org/10.1084/jem.20021980

Watt, N.T., and Hooper, N.M. (2005). Reactive oxygen species (ROS)-mediated beta-cleavage of the prion protein in the mechanism of the cellular response to oxidative stress. Biochem. Soc. Trans. 33, $1123-1125$.

Watts, J.C., Drisaldi, B., Ng, V., Yang, J., Strome, B., Horne, P., Sy, M.S., Yoong, L., Young, R., Mastrangelo, P., et al. (2007). The CNS glycoprotein Shadoo has $\operatorname{PrP}(\mathrm{C})$-like protective properties and displays reduced levels in prion infections. EMBO J. 26, 4038-4050.

Watts, J.C., Bourkas, M.E.C., and Arshad, H. (2018). The function of the cellular prion protein in health and disease. Acta Neuropathol. 135, 159-178. https://doi.org/10.1007/s00401-017-1790-y

Weise, J., Sandau, R., Schwarting, S., Crome, O., Wrede, A., Schulz-Schaeffer, W., Zerr, I., and Bähr, M. (2006). Deletion of cellular prion protein results in reduced Akt activation, enhanced postischemic caspase-3 activation, and exacerbation of ischemic brain injury. Stroke 37, 1296-1300.

Westaway, D., DeArmond, S.J., Cayetano-Canlas, J., Groth, D., Foster, D., Yang, S.L., Torchia, M., Carlson, G.A., and Prusiner, S.B. (1994). Degeneration of skeletal muscle, peripheral nerves, and the central nervous system in transgenic mice overexpressing wild-type prion proteins. Cell 76, 117-129.

White, M.D., Farmer, M., Mirabile, I., Brandner, S., Collinge, J., and Mallucci, G.R. (2008). Single treatment with RNAi against prion protein rescues early neuronal dysfunction and prolongs survival in mice with prion disease. Proc. Natl. Acad. Sci. U.S.A. 105, 10238-10243. https://doi.org/10.1073/ pnas.0802759105

Winklhofer, K.F., Tatzelt, J., and Haass, C. (2008). The two faces of protein misfolding: gain- and loss-of-function in neurodegenerative diseases. EMBO J. 27, 336-349. https://doi.org/10.1038/ sj.emboj. 7601930

Wulf, M.A., Senatore, A., and Aguzzi, A. (2017). The biological function of the cellular prion protein: an update. BMC Biol. 15, 34. https://doi.org/10.1186/s12915-017-0375-5

Yehiely, F., Bamborough, P., Da Costa, M., Perry, B.J., Thinakaran, G., Cohen, F.E., Carlson, G.A., and Prusiner, S.B. (1997). Identification of candidate proteins binding to prion protein. Neurobiol. Dis. 3, 339-355.

Yokoi, M., Mori, K., and Nakanishi, S. (1995). Refinement of odor molecule tuning by dendrodendritic synaptic inhibition in the olfactory bulb. Proc. Natl. Acad. Sci. U.S.A. 92, 3371-3375.

Yu, G., Chen, J., Xu, Y., Zhu, C., Yu, H., Liu, S., Sha, H., Chen, J., Xu, X., Wu, Y., et al. (2009). Generation of goats lacking prion protein. Mol. Reprod. Dev. 76, 3. https://doi.org/10.1002/mrd.20960

Zafar, S., von Ahsen, N., Oellerich, M., Zerr, I., Schulz-Schaeffer, W.J., Armstrong, V.W., and Asif, A.R. (2011). Proteomics approach to identify the interacting partners of cellular prion protein and characterization of Rab7a interaction in neuronal cells. J. Proteome Res. 10, 3123-3135. https://doi. org/10.1021/pr2001989

Zanata, S.M., Lopes, M.H., Mercadante, A.F., Hajj, G.N., Chiarini, L.B., Nomizo, R., Freitas, A.R., Cabral, A.L., Lee, K.S., Juliano, M.A., et al. (2002). Stress-inducible protein 1 is a cell surface ligand for cellular prion that triggers neuroprotection. EMBO J. 21,3307-3316. https://doi.org/10.1093/emboj/cdf325

Zeng, F., Watt, N.T., Walmsley, A.R., and Hooper, N.M. (2003). Tethering the N-terminus of the prion protein compromises the cellular response to oxidative stress. J. Neurochem. 84, 480-490.

Zhang, C.C., Steele, A.D., Lindquist, S., and Lodish, H.F. (2006). Prion protein is expressed on long-term repopulating hematopoietic stem cells and is important for their self-renewal. Proc. Natl. Acad. Sci. U.S.A. 103, 2184-2189. 